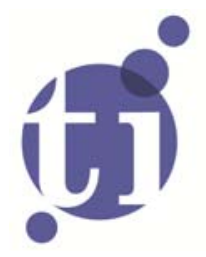

\title{
The Value of an Educated Population for an Individual's Entrepreneurship Success
}

José Maria Millán ${ }^{A}$

Emilio Congregadot

Concepción Román ${ }^{4}$

Mirjam van Praag, ${ }^{B, D}$

André van Stelc

A University of Huelva, Spain;

B Copenhagen Business School, Denmark, Faculty of Economics and Business, University of Amsterdam, and Tinbergen Institute, the Netherlands;

C Panteia/EIM, Zoetermeer, the Netherlands;

DTinbergen Institute, the Netherlands. 
Tinbergen Institute is the graduate school and research institute in economics of Erasmus University Rotterdam, the University of Amsterdam and VU University Amsterdam.

More TI discussion papers can be downloaded at http://www.tinbergen.nl

Tinbergen Institute has two locations:

Tinbergen Institute Amsterdam

Gustav Mahlerplein 117

1082 MS Amsterdam

The Netherlands

Tel.: +31(0)205251600

Tinbergen Institute Rotterdam

Burg. Oudlaan 50

3062 PA Rotterdam

The Netherlands

Tel.: +31(0)10 4088900

Fax: $+31(0) 104089031$

Duisenberg school of finance is a collaboration of the Dutch financial sector and universities, with the ambition to support innovative research and offer top quality academic education in core areas of finance.

DSF research papers can be downloaded at: http://www.dsf.nl/

Duisenberg school of finance

Gustav Mahlerplein 117

1082 MS Amsterdam

The Netherlands

Tel.: +31(0)20 5258579 


\title{
The value of an educated population for an individual's entrepreneurship success
}

Accepted for publication in the

\author{
José María Millán ${ }^{\mathrm{A}}$, Emilio Congregado ${ }^{\mathrm{A}}$, Concepción Román ${ }^{\mathrm{A}}$, \\ Mirjam van Praag ${ }^{\mathrm{B}, \mathrm{D}}$, and André van Stel ${ }^{\mathrm{C}, \mathrm{D}}$ \\ ${ }^{\mathrm{A}}$ University of Huelva, Spain

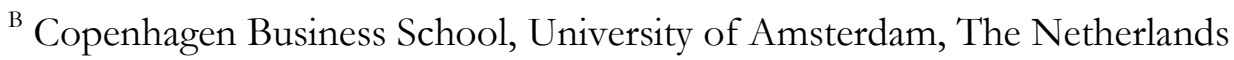 \\ ${ }^{\mathrm{C}}$ Panteia/EIM, Zoetermeer, The Netherlands \\ ${ }^{\mathrm{D}}$ Tinbergen Institute, The Netherlands
}

\begin{abstract}
:
Human capital obtained through education has been shown to be one of the strongest drivers of entrepreneurship performance. The entrepreneur's human capital, though, is only one of the input factors into the production process of her venture. In this paper we will analyze to what extent the education levels of other (potential) stakeholders affect the entrepreneur's performance. The education level of consumers may shape the demand function for an entrepreneur's output, whereas the education level of employees may affect the entrepreneur's productivity and thereby shape her supply function. Based on this, we hypothesize that the performance of an entrepreneur is not only affected positively by her own education level but in addition, also by the education level of the population. We find empirical support for this hypothesis using an eight years (1994-2001) panel of labor market participants in the EU-15 countries. An implication of our finding is that entrepreneurship and higher education policies should be considered in tandem with each other.
\end{abstract}

Keywords: entrepreneurship, performance, survival, personnel, (tertiary) education, production function

Contact: José María Millán, jose.millan@dege.uhu.es

Version: September 2013

Document: Full manuscript R4 Sep 2013.doc

Acknowledgement: The paper has greatly benefited from the constructive comments of the associate editor Simon Parker and three anonymous referees. We are also grateful to conference and seminar participants at various places for their suggestions. The usual disclaimer applies. We acknowledge financial support from ACE (UvA), the research program SCALES (www.entrepreneurship-sme.eu) and the Spanish Ministry of Education (Programa Nacional de Movilidad de Recursos Humanos, Plan Nacional de I+D+i 2008-2011). 


\section{Executive Summary}

One of the strongest drivers of entrepreneurship success is the entrepreneur's human capital obtained through education. The human capital of the entrepreneur herself is, though, not the only human capital that determines the success of the entrepreneur's venture. The education levels of other (potential) stakeholders may also affect the entrepreneur's venture performance. In particular, the education level of consumers may shape the demand function for an entrepreneur's venture output, whereas the education level of employees may affect the entrepreneur's venture productivity and thereby shape her supply function. However, very little is known about this perspective on the relationship between education and entrepreneurship, despite its importance for entrepreneurs and public policy makers. Filling this research lacuna is the main aim of this work, that is, to investigate the effect of the population distribution of education on an entrepreneur's venture performance (on top of the effect of the entrepreneur's own education level). Almost all of the earlier work on the relation between human capital and entrepreneurship outcomes focuses either on the regional level or on the individual level, whereas our research combines the use of individual and regional data. Therefore, our study is relatively adequate to measure the causal impact of the population's distribution of education on entrepreneurial performance on top of the returns to the individual education level of the entrepreneur. Our study focuses on European entrepreneurs.

We first develop a theoretical framework based on the existing literature to establish how a higher educated local population may affect venture performance of individual entrepreneurs via two intermediate mechanisms: (i) a working population of higher quality; and (ii) a more sophisticated and diverse consumer market. Regarding the first mechanism we argue that entrepreneurial firms tend to benefit from the greater supply of these high quality human capital resources that can be employed in their workforce. Regarding the second mechanism we argue that consumer wants of higher educated consumers may lead to more differentiated consumer demand and to a higher level of demand for innovative products and services. As a consequence, new (niche) business opportunities will likely emerge and entrepreneurial firms are likely to benefit from these. We also discuss the nuances of market conditions in which entrepreneurial firms might benefit from these demand and supply effects of an educated population relative to incumbent or large firms. The theoretical section concludes with the hypothesis that the performance of an entrepreneur is not only affected positively by her own education level but in addition, also by the share of highly educated individuals in the (local) population. This hypothesis is tested in the sequel of the paper. 
For empirical testing, we exploit a large longitudinal dataset, the European Community Household Panel (ECHP-Eurostat), which contains detailed information on demographics, education, labor market status and incomes for about 60,500 nationally representative households (approximately 130,000 individuals aged 16 years and older) in the EU-15 countries. The business outcomes that can be obtained from this data source and that we estimate are (i) the survival of an entrepreneur's business; (ii) the earnings of an entrepreneur; (iii) the likelihood that any entrepreneur starts employing personnel and thus becomes an employer; and (iv) the probability that an entrepreneur survives as an employer, given that the entrepreneur employs personnel. The former two measures are commonly used within existing empirical literature, whereas the latter two are used less frequently in research but informative for policy. Studying these can contribute to our understanding of the growth of firms.

Our main explanatory variable is the local population's share of higher educated individuals. We propose four different operationalizations of this variable by combining two different dimensions. First, regarding higher education, we refer to the share of the active population with either tertiary education or at least upper secondary education. Second, regarding the definition of 'local population', we refer to either a country's population or a region's population (at NUTS-1 spatial aggregation level).

The econometric specifications we employ to estimate the effect of the local population's education level on our four performance variables all identify a positive impact. We thus obtain strong evidence supporting the validity of our hypothesis, i.e., a population's share of highly educated individuals has a positive impact on individual entrepreneurship performance. Entrepreneurs do not only earn more or survive longer when the population includes a larger percentage of highly educated individuals. They are also more likely to employ personnel and they remain employers for a longer period of time. These results are robust to different operationalizations of higher education and local population.

Our result indicates that entrepreneurial firms, i.e., firms that are young or even new and therefore most often small, benefit from the presence of an educated workforce and/or educated consumers in their environment. Our study implies that educational policies may be viewed as an additional instrument to develop high quality entrepreneurial businesses. The appeal of this instrument is that it does not require to 'pick winners' upfront, which is obviously difficult, if not 
impossible. Admittedly, few policy makers will have doubted the value of education. The contribution of our result lies in the fact, though, that the education level of the population can be viewed and used as a direct instrument to develop high quality entrepreneurship irrespective of the labor market choices that these educated people make (i.e., entrepreneurship versus wage employment).

\section{Introduction}

Human capital obtained through education has been shown to be one of the strongest drivers of entrepreneurship performance (cf., the overviews in Unger et al., 2011 and Van der Sluis et al., 2008). Citing the conclusion in Parker's handbook from an encompassing review of the empirical literature of the drivers of entrepreneurship performance:

Overall, the literature suggests that human capital is the major determinant of entrepreneurs' earnings ( $V$ an Praag, 2005, p. 9). Few other explanatory variables, including ethnicity, family background, social capital, business strategy, or organisational structure of the venture, possess as much explanatory power, Parker (2009), p. 582.

The human capital of the entrepreneur herself is, though, only one of the input factors into the production process of her venture. In this paper we will analyze to what extent the education levels of other (potential) stakeholders affect the entrepreneur's performance. The education level of consumers may shape the demand function for an entrepreneur's output, whereas the education level of employees may affect the entrepreneur's productivity and thereby shape her supply function.

We expect that a higher share of people with high levels of education (to be defined more precisely) has a positive impact on the performance of the average entrepreneur. A population with a higher education level may, ceteris paribus, be associated with (i) a working population of higher quality; and (ii) a more sophisticated and diverse consumer market. In other words, on the one hand, a more highly educated working population increases the supply of human capital that is associated with more productivity and innovation (Gennaioli et al., 2013). At the individual level, entrepreneurs may benefit as it will be easier to find qualified personnel. On the other hand, a more highly educated consumer market affects the demand for consumer products positively in a qualitative sense such that the demand for innovativeness and diversity increases. At the individual level, entrepreneurs may benefit from a more diverse consumer demand as it will create op- 
portunities to enter and exploit niche markets. Based on these mechanisms, to be made more precise in the sequel, we will develop the following hypothesis: The performance of an entrepreneur is not only affected positively by her own education level but in addition, also by the share of highly educated individuals in the (local) population.

Almost all of the earlier work on the relation between human capital and entrepreneurship outcomes focuses either on the regional level (e.g., Acs and Armington, 2004) or on the individual level (see Unger et al., 2011), whereas our research question requires the combined use of data at both these two units of observation. We are aware of one exception which, for the United States, do use combined data at both observation levels (Doms et al., 2010). However, these authors find mixed results for the two different data sets used in their study, disallowing them to reach a conclusion about the relation between regional human capital levels and entrepreneurial performance. These mixed results call for more research in this area. Moreover, these authors put forward the possibility that the relation may be sensitive to the level of spatial aggregation employed. In our paper we combine regional level human capital data with micro-level data on entrepreneurial performance for a set of European countries. Furthermore, we apply our models for different levels of spatial aggregation.

We test our hypothesis empirically based on an eight years (1994-2001) panel of labor market participants in the EU-15 countries. We select from this Eurostat European Community Household Panel (ECHP) survey those labor force participants who have been observed as entrepreneurs for at least one spell during the period of observation. The individual entrepreneurship outcomes that can be obtained from this data source and that we estimate are (i) the survival of an entrepreneur's business; (ii) the earnings of an entrepreneur; (iii) the likelihood that any entrepreneur starts employing personnel and thus becomes an employer; and (iv) the probability that an entrepreneur survives as an employer, given that the entrepreneur employs personnel. We append to these data a harmonized set of annual data on national level variables including indicators of educational attainment as well as a set of regional education variables. Thus, we can establish the main relationship of interest, i.e., between the performance of individual entrepreneurs and the population distribution of education in their country (or region) and year of operation, while controlling for other relevant sources of heterogeneity between countries (regions) and over time. Using our specific set of measures of entrepreneurial performance, we address a research question raised by Acs and Armington (2004) who ask whether "human capital characteristics of regions [also] influence the survival, growth and failure of [new] firms?” (p. 270). 
In particular, the availability of skilled or advanced human capital is important for growth and innovation in developed countries (Czarnitzki and Hottenrott, 2009, Vandenbussche et al., 2006). We therefore employ as our main measure of education a population's share of individuals with tertiary education. Particularly tertiary education, rather than other levels of education, has been found to be important for innovation and endorsing economic growth in developed economies (Hanushek and Woessmann, 2008). A second measure of the education level of the population that we employ, also to avoid a somewhat elitist view, includes the population share of individuals with at least upper secondary education. We thus measure the population distribution of education in terms of the share of the active population with tertiary (or upper secondary) education in country (or region) $j$ and year $t$.

We find support for a positive impact of a population's share of highly educated individuals (primarily those with tertiary education) in country or region $j$ and year $t$ on the various measures of the performance of individual entrepreneurs in that same country (region) and year. All performance measures studied, i.e., venture survival, earnings and the probability that an entrepreneur starts employing personnel and remains an employer are affected significantly and positively by the share of highly educated individuals.

Our result indicates that entrepreneurial firms, i.e., firms that are young or even new and therefore most often small (Van Praag and Versloot, 2008), benefit from the presence of an educated workforce and/or educated consumers in their -obviously competitive- environment. The economic rents caused by the higher educated population in a region are to a considerable extent captured by the collective group of entrepreneurs in a region and not only by their larger and older counterparts, the 'non-entrepreneurial' firms (see Van Praag and Versloot, 2008) in the same region.

Our study implies that educational policies may be viewed as an additional instrument to develop high quality entrepreneurial businesses. The appeal of this instrument is that it does not require to 'pick winners' upfront, which is obviously difficult, if not impossible (Shane, 2009). Admittedly, few policy makers will have doubted the value of education. The implication of our result, though, is that the education level of the population can be viewed and used as a direct instrument to develop high quality entrepreneurship irrespective of the labor market choices that these educated people make (i.e., entrepreneurship versus wage employment). 
The organization of the paper is as follows. Section 2 discusses the theory relevant to our hypothesis. Section 3 describes the data and discusses the empirical methodology. In Section 4 we present and discuss the results. Section 5 concludes.

\section{Theory and literature}

\subsection{The supply function of the entrepreneur's product}

The relation between a firm's input and output can be described by means of a production function. As an example, we take the traditional Cobb-Douglas production function which can be represented as:

$Y=A L^{\alpha_{1}} K^{\alpha_{2}}$

where $Y, L$ and $K$ represent quantities of output, labor and capital inputs, respectively. Parameter $A$ is usually defined as the entrepreneur's productivity or efficiency to create outputs from inputs. The entrepreneur's productivity depends (among other factors) on the technical knowledge, the productive effectiveness and the ability of acquiring new knowledge of the entrepreneur (Calvo and Wellisz, 1980).

The individual production function of an entrepreneur thus readily reveals the potential importance of education for the performance of entrepreneurs through two factors that will be discussed in more detail below. The first is the entrepreneur's education level that will affect her productivity and thus her productive performance positively. The second is the productivity of a unit of labor, $L$, which is measured by $\alpha_{1}$ and is likely to be dependent on the human capital and thus the education of the worker.

\subsubsection{The entrepreneur's education level}

A basic proposition derived from human capital theory is that education leads to higher productivity and thus to higher income (Mincer, 1958; Becker, 1964). It has been contended that, in general, previously acquired knowledge plays a critical role in intellectual performance, also assisting in the integration and accumulation of new knowledge as well as the adaptation to new situations (Weick, 1996). This proposition has been widely supported empirically for the employment probabilities and incomes of wage employees (Ashenfelter et al., 1999) and for the business per- 
formance and incomes of entrepreneurs (see for instance, Bates, 1990; Burke et al., 2000; Cooper et al., 1994; Davidsson and Honig, 2003; Fairlie and Robb, 2007; Henley, 2005; Millán et al., 2013a; Robinson and Sexton, 1994 and Van Praag et al., 2013, as well as the meta-analyses of Unger et al., 2011 and Van der Sluis et al., 2008).

Schooling is not only acknowledged for its productive effect, as assumed by Mincer, but also for its value as a signal of productive ability in labor markets without complete information (Spence, 1973). This may lead to positive returns to education as well. Recent studies show that entrepreneurs may use their education as a signal toward suppliers of capital (Parker and Van Praag, 2006) or (prospective) customers and highly qualified employees (Backes-Gellner and Werner, 2007).

All in all, we expect that the education level of the entrepreneur has a positive association with her business performance.

\subsubsection{The workers' education level}

'Although a large empirical literature suggests that worker outcomes are associated with firm characteristics ....., very little is known about the converse- the process by which business outcomes are associated with the characteristics of their employees' (Haltiwanger et al., 1999, p. 94).

Human capital theory predicts that workers with higher levels of human capital obtained through education are more productive. Empirical evidence at the individual level abounds (Ashenfelter $e t$ al., 1999). However, the increased productivity has to be remunerated by employers. Therefore, rational entrepreneurs optimize their demand for employees with higher education. When the supply of these productive workers is less restricted, entrepreneurs may be able to hire a number of them closer to the optimum which leads to higher firm performance.

The theoretical justification for a positive impact of the human capital of employees on firm performance is probably best rooted in the resource based view of the firm (Wernerfelt, 1984; Barney, 1991): The competitive advantage of firms is based on the valuable resources at their disposal. Human capital is one of the critical resources in the development of innovations and, ultimately, the creation and maintenance of a competitive advantage (e.g., Barney and Wright, 1998). A substantial share of the human capital of firms resides with the workforce (e.g., Subramaniam and Youndt, 2005) and is obtained through formal education. More in particular, highly educated workers contribute to both process and product innovations. Empirical studies confirm this at 
the individual level (Bishop, 1994), the firm level (Blundell et al., 1999; Toole and Czarnitzki, 2009) and the regional level (Czarnitzki and Hottenrott, 2009).

\section{Entrepreneurial versus non-entrepreneurial firms}

The value creation caused by increased human capital in the regional labor market does not necessarily carry over to a stronger performance of the group of entrepreneurs in the region. It might be that this value creation is solely captured by incumbent, older and often larger firms, i.e., the entrepreneurs' competitors in the regional (product and) labor markets. Nevertheless, this is unlikely to be the case. In general, the increased (macro-)economic value associated with higher levels of human capital at the regional/country level (Gennaioli et al., 2013) is likely to benefit all organizations and individuals in that region, including entrepreneurs.

Moreover, a larger availability of human capital is likely to benefit entrepreneurial firms in particular as their employment optimization problem is often more restricted compared to nonentrepreneurial firms. For instance, Dutch survey evidence indicates that, in general, entrepreneurial firms experience more difficulties in finding and attracting personnel (with higher education levels) than their counterparts and that this is a severe bottleneck for further growth of their venture (Van Praag et al., 2009). Entrepreneurial firms will face even stronger obstacles to recruit educated personnel in regions with scarce availability of highly educated candidates, thereby decreasing their performance (Haltiwanger et al., 1999). Hence, a larger supply of highly educated employees is likely to alleviate these problems of entrepreneurs in particular (i.e. the larger supply is likely to relax the entrepreneur's employment optimization problem to a greater extent compared to the non-entrepreneur's optimization problem). However, we should note here that this relative benefit for entrepreneurial vis-à-vis non-entrepreneurial firms could cease to apply if entrepreneurial and non-entrepreneurial firms compete in the same labor market and, in spite of the arguments above, the non-entrepreneurial firms hire the vast majority of the increased supply of highly educated workers at the cost of entrepreneurial firms. Below we argue why the realistic property of this condition is limited.

The competition between entrepreneurial and non-entrepreneurial firms in the (highly educated) labor market is far from perfect. First, entrepreneurial firms use distinct recruiting channels relying on social networks, rather than formal channels which are used more often by nonentrepreneurial firms (e.g., Barber et al., 1999; Carroll et al., 1999; Deshpande and Golhar, 1994 and Tanova, 2003). Second, entrepreneurial firms have a different appeal to potential employees 
than non-entrepreneurial firms. Entrepreneurs may attract workers who attach a higher value to job satisfaction and autonomy and a lower value to wage levels. Employees in entrepreneurial firms have higher levels of job satisfaction, on average (Benz and Frey, 2008; Clark, 1996; Idson, 1990; Millán et al., 2013b) possibly due to more autonomy (Benz and Frey, 2008; García-Serrano, 2011; Idson, 1990) ${ }^{1}$, although they receive lower pay (e.g., Brown and Medoff, 1989; Elfenbein et al., 2010; Oi and Idson, 1999; Schmidt and Zimmermann, 1991) and the pay difference is especially large for workers with higher levels of education (Hollister, 2004).

The observations described above indicate that entrepreneurs would indeed benefit from a larger supply of more highly educated workers in the regional labor market and increase their performance.

\section{Effect of educated workforce on the various performance measures of entrepreneurs}

So far, we discussed the effect of an educated workforce on entrepreneurial performance in general. Below, we discuss how a more highly educated workforce may specifically contribute to the various firm performance measures used in this study, i.e., survival, earnings, and (employment) growth.

A more educated workforce is associated with a more productive and innovative (regional) economy (Gennaioli et al., 2013). As we just discussed, entrepreneurial firms in the region/country are likely to benefit by being more able to attract qualified personnel. The less restricted supply of suitable employees may enable them to hire a greater or more optimal number of employees. Thus, this may have a direct and positive effect on the decision to become an employer and on the number of employees. Moreover, alleviating this possible restriction will have a direct impact on competitiveness and hence on survival (Geroski et al., 2010) and earnings and an indirect effect on earnings via the possibly increased levels of innovation. ${ }^{2}$ All in all, we expect that a workforce in which more individuals have higher education levels affects all performance measures we study positively. We note though that these effects apply only to the minority of entrepreneurs that do employ personnel and/or have the ambition to grow and employ (more) personnel.

\subsection{The demand for the entrepreneur's product}

\footnotetext{
${ }^{1}$ Some older studies indicate that small firms offer a more personal work atmosphere (Lester, 1967), less formal work rules and regimentation (Masters, 1969), and have the advantage of shorter commuting (Scherer, 1976).

2 Process innovation may lower unit costs which may lead to increased profit margins, or, if output price is also reduced and price elasticity is high, to increased turnover. Product innovation may enable entrepreneurs to tap into new market demand, which in turn may increase the entrepreneur's earnings.
} 
Supply-side considerations alone may be insufficient to account for the effect of the population's education level on the performance of individual entrepreneurs. Consumer demand is also a determining (but often neglected) factor, especially of innovation (Buenstorf, 2003; Witt, 2001). Consumer demand is shaped by various characteristics of the consumer population. Education has been put forth, besides consumer wealth (Jackson, 1984) as an important factor affecting preferences for variety and innovative products and services (Witt, 2001). Education, besides experience, develops the (subjective) consumption knowledge of individuals (Witt, 2001). Witt concludes that cognitive learning leads to new ways of satisfying innate wants, and, in particular, satisfying them in new combinations. Moreover, the set of wants which people have is not invariant and also affected by non-cognitive learning (Witt, 2001). Cognitive and non-cognitive learning reinforce each other (Cunha and Heckman, 2010; Witt, 2001).

Thus, cognitive learning as developed in school has a direct and indirect effect on the formation of consumption activities. Both consumer wants and consumption knowledge become more detailed and induce specialization in consumption (Witt, 2001, pp. 30-31) and may thereby shape the demand for innovation. Education also features the desire of individuals to develop an identity that leads to specific and detailed preferences (Benn, 2004). Preferences for variety or differentiation have a positive effect on business opportunities through the demanded development of new and alternative products and services in new (often niche) markets (Wennekers et al., 2010).

This may imply that a population with a higher level of education leads to more differentiated consumer demand and to a higher level of demand for new and innovative products and services. As a consequence, new (niche) business opportunities will likely emerge. These newly created niche opportunities will improve the competitive position of entrepreneurial firms compared to non-entrepreneurial firms as the former are better equipped to respond to these opportunities due to their smaller scale (Aldrich and Auster, 1986; Katz, 1970) and their greater speed and flexibility (Dean et al., 1998). For instance, largeness is associated with structural complexity and bureaucracy (Mintzberg, 1979), constraining information-processing capacity (Galbraith, 1977) and the speed of competitive activity (Chen and Hambrick, 1995; Singh, 1990; Smith et al., 1991). Moreover, large firms tend to be risk averse (Hitt et al., 1990), and they are more likely to be under regulatory and public scrutiny, which may limit their competitive leeway (Bloom and Kotler, 1975; Cooper et al., 1986; Fombrun and Shanley, 1990; Scherer, 1980).

\section{Entrepreneurial versus non-entrepreneurial firms}


Results by Dean et al. (1998) suggest that small and large firms possess different resources and capabilities that make them particularly well suited to different environmental contexts. In particular, their study indicates that growing industry niches are relatively more attractive to small businesses. These entrepreneurial firms are more likely to enter industry environments in which speed, flexibility, and niche targeting are rewarded. In contrast, large business are more likely to successfully enter and operate in industries in which deep pockets, economies of scale, and broad-based strategies are most advantageous. Differentiated consumer demand and the associated presence of growing niches (even in the absence of overall industry demand growth), may therefore cause particular business opportunities for entrepreneurs -with the capabilities of speed, flexibility and niche-filling-(Astley, 1985; Dean and Meyer, 1996; Dean et al., 1998).

The above studies are in accordance with the theory of strategic niches (Porter, 1979; Caves and Porter, 1977): Small firms provide a different economic function than their larger counterparts. They do not compete directly with them and can provide complementary rather than competitive products/services (Nooteboom, 1994). In general, large firms avoid supplying the market niches (Haveman and Nonnemaker, 2000), thus leaving market gaps for small and entrepreneurial organizations, for fear of sales cannibalization (Ghemawat, 1991) or costly aggressively competitive actions (Lee et al., 1999). ${ }^{3}$

\section{Effect of educated workforce on the various performance measures of entrepreneurs}

The increased demand for product variety resulting from a higher educated consumer population provides room for entrepreneurial firms to enter and exploit niche markets or even to create new uncontested market space where competition is 'irrelevant' (Kim and Mauborgne, 2005). There are plenty of examples of highly specialized consumerism: gourmet food, handcrafted jewelry, sports equipments, arts and crafts, etc. due to unlimited innovation possibilities. Higher demand will also increase profits. Moreover, the amount of competition in niche markets or entirely new markets is often relatively low, which increases survival chances. It also provides firms some flexibility to set their output price, which will also positively affect firm profits.

All in all, we expect that differentiated consumer demand resulting from a highly educated population will positively influence the performance of entrepreneurs (most of whom run small firms).

\footnotetext{
${ }^{3}$ But, even if bigger firms choose to compete aggressively in the niches supplied by smaller ones, alternative strategies are still available for smaller firms as suggested by Lee et al. (1999): (i) the free-riding strategy - exploiting the market development efforts of the bigger rivals by offering products identical to theirs, and (ii) forming strategic alliances to gain competitive advantages over the bigger rivals and/or to deter them from adopting aggressive competitive actions against their smaller counterparts.
} 
We expect that this applies to all different performance measures: survival, entrepreneurs' earnings and the decision to hire workers.

\subsection{Hypothesis}

We have motivated that two mechanisms potentially explain the expected positive relationship between the share of the population with a high education level and the business performance of entrepreneurs. First, a higher share of individuals with high education will increase the likelihood that entrepreneurs can attract employees with high education and thus grow and prosper with the help of this input into the production process. Second, a population with a higher share of individuals with high education implies a more differentiated consumer demand and a higher level of demand for innovative products and services. This affects business opportunities and performance positively. We formulate the following hypothesis:

There is a positive relationship between the share of the population with a high level of education in a certain region and year and the business outcomes of individual entrepreneurs in the same region and year.

In the next section, we discuss the measurement of business performance, the population distribution of education and regions.

\section{Empirical methodology and data}

\subsection{Data}

The panel data used are taken from the European Community Household Panel (ECHP). The ECHP is a standardized multi-purpose annual longitudinal survey carried out at the level of the EU-15 $5^{4}$ covering the period 1994-2001. ${ }^{5}$ It was centrally designed and coordinated by the Statistical Office of the European Communities (Eurostat). Every year, all members of the selected households in each country are interviewed about demographics, education, labor market status and outcomes. The same questionnaire is used for all countries and years (see Peracchi, 2002, for a discussion).

\footnotetext{
${ }^{4}$ Sweden is excluded from all analyses due to missing values for relevant variables. France and Luxembourg are excluded from our analyses on transitions from own-account worker to employer, and employership survival because relevant data are missing. The Netherlands is also excluded from the analysis of employership survival due to the low number of new employers detected. In our exercises, the minimum number of countries included is 11, while the number of years is 7 (period 19942001). Hence the minimum number of different country-year observations is 77 , which is sufficient, considering the number of country-level variables in our model (6).

5 The ECHP data are used with the permission of Eurostat (contract ECHP/2006/09, held with the Universidad de Huelva).
} 
From the self-reported annual labor market status information we construct a variable that indicates whether one is an entrepreneur in each of the years (within-year changes are not recorded). Following the occupational notion of entrepreneurship (Sternberg and Wennekers, 2005), entrepreneurship is equated to business ownership. We acknowledge the use of various definitions of entrepreneur in the literature (Parker, 2009, Ch. 1). The most commonly used measure is business ownership or self-employment. This definition includes all 'residual claimants', i.e. labor market participants without an employer and who do own their business, i.e., who assume the risk of their business activities. Alternative definitions are (i) business owners who employ others, (ii) those who introduce 'paradigm shifting' innovations (the Schumpeterian view), (iii) new venture creation or nascent entrepreneurship. Admittedly, the measure we use can include people who are unlikely to be entrepreneurs according to other criteria, for instance the Schumpeterian based view. Moreover the measure excludes many of the entrepreneurs according to another commonly used definition, i.e., the nascent entrepreneurs, who are often still wage employed (Parker, 2009, Ch. 1). A practical matter that guides our choice for this commonly used measure is that the 'business ownership' measure is available in the dataset we employ and in a comparable fashion across all regions, countries and years we study.

A distinction is made in our study, on an annual basis, between business owners with and without employees. Entrepreneurs without personnel are labeled own-account workers and those with employees, employers. This allows us employing a mixture of entrepreneurship measures as was suggested by Gartner and Shane (1995). The data further allow a distinction between nonemployment and paid employment. Hence, each individual is observed in a particular year in one of these four labor market statuses. The sample we use is restricted to individuals who have been observed as entrepreneurs in at least one of the years 1994-2001. We further restrict the sample to men and women aged 21 to 59 to exclude any possible exits out of entrepreneurship due to retirement. As usual, the agricultural industries are excluded from the analysis because of structural sector differences with the rest of the economy. Finally, we exclude entrepreneurs from the sample who work part-time (less than 15 hours per week). ${ }^{6}$

\subsection{Defining and explaining business performance}

We are interested in explaining variations in the business performance of individual entrepreneurs. First, we consider the usual performance measure 'survival of the entrepreneur's business'.

\footnotetext{
${ }^{6}$ The main results are not sensitive to the chosen threshold level.
} 
Second we employ the variable 'earnings of an entrepreneur' (in natural logarithm). This variable is defined by the self-employment income earned in the year of the interview (in euro's of 1996) and made comparable across countries (by a correction based on Purchasing Power Parities) and over time (by applying the Harmonised Consumer Price Index). ${ }^{7}$ Third, we consider the performance measure 'switch from own-account worker to employer'. The fourth performance measure is 'survival as an employer' given that an entrepreneur has reached the state of employer from own-account work. All these measures are constructed using data from the ECHP.

Earnings equations are estimated by means of tobit regressions. We use tobit because a considerable proportion of observations (about 15\%) are zero's. In these cases the entrepreneur either only earns just enough to cover business expenses or might suffer losses. To study the transition probability from own account work (entrepreneur without personnel) to employer (entrepreneur with personnel) a binary logit model is estimated. The survival probabilities as entrepreneur (own account worker and employer) and as employer are estimated using survival models. We distinguish two competing exit destinations from the status of entrepreneur: To unemployment/inactivity and to paid employment. The survival model of employership is estimated in a single risk framework, combining all exit routes into a single category. ${ }^{8}$ For the estimation of both survival models we use the logistic hazard function (as opposed to, for instance, a generalized gamma function) $)^{9}$ to cope with the discretely measured duration data we have. ${ }^{10}$

All regressions control for unobserved heterogeneity across individuals by means of random effects models (Wooldridge, 2002). Unobserved heterogeneity may be a concern because if the factors that are not explicitly included in the model are correlated with those included, the estimated effects of the latter may be biased. As we are interested in explaining variations in performance between individuals from variations in education between individuals as well as between

\footnotetext{
${ }^{7}$ Obviously, the entrepreneurs in our sample report incomes earned in the year prior to the interview. Therefore, all explanatory variables are 1 -year lagged in order to avoid timing mismatch with earnings when running earning equations.

${ }^{8}$ For this exercise we do not use a competing risk model because the number of transitions from employer to non-employment statuses is too low.

${ }^{9}$ We use the multinomial logit model when considering two competing hazards, given the discrete values of the choices involved. It assumes that the categories of a model's dependent variable are distinct from each other, i.e., the independence of irrelevant alternatives (IIA). Without any reliable test for this IIA assumption (see Cheng and Long, 2007 and Long and Freese, 2006) we rely on the early contributions by McFadden (1974), who argued that MNL models should be used only in cases where the alternatives can plausibly be assumed to be distinct and weighted independently in the eyes of the decision maker. In similar terms, Amemiya (1981) suggests that the MNL model works well when the alternatives are dissimilar. We assume this is the case here.

10 The survival analyses only include individuals who first became entrepreneur or employer during the sample period (i.e. in the period 1994-2001). Therefore, there are no left-censored observations. The sample does include right-censored observations, though, besides completed entrepreneurship and employership spells. The right-censored observations are the spells that are still in progress in 2001.
} 
countries, we use random effects models. An advantage of random effects models is that it allows estimation of the effects of time-invariant determinants. ${ }^{11}$ However, random effects models rely on a strong identifying orthogonality assumption ensuring that the estimates do not suffer from omitted variable bias. Unfortunately, the usual Hausman test to formally assess whether this assumption is met cannot be performed. It requires estimating fixed effects models, which is not applicable for our survival and transition analyses and which may result in biased and inconsistent estimates in the case of tobit regressions (Greene, 2004). ${ }^{12}$ Admittedly, using random effects models while not being able to assess the validity of the orthogonality assumption is a limitation of our study. Nevertheless, we have a priori no reason to suspect that omitted variable bias occurs in our model: we include six individual-level control variables, including the most commonly accepted determinants of entrepreneurial performance (see Section 3.4). ${ }^{13}$

The four estimation models are used to measure the effect of the share of a (local) population with tertiary (or upper secondary) education on the four measures of business performance of individual entrepreneurs. In the main specifications, the 'local' population is considered to be a country's population. However, since labor and consumer markets are to some extent regionally oriented, particularly in some of the larger EU-countries such as the UK, Germany and France, we will also perform our empirical exercises using education indicators at the regional (NUTS-1) level.

\subsection{Main explanatory variable: Educational attainment at the macro level}

Finding a relevant and measurable characterization of the education level of the (local) population is challenging. On the one hand, if strictly considering skilled or advanced human capital (given its importance for growth and innovation in developed countries; see e.g. Czarnitzki and Hottenrott, 2009 or Vandenbussche et al., 2006), the share of the active population holding tertiary education seems an appropriate proxy. On the other hand, individuals with 'only' (upper) secondary education can posses certain kinds of knowledge and abilities that may be valuable for an employer. In parallel, they can be as sophisticated consumers as those with tertiary education

\footnotetext{
11 Note that education levels hardly vary over time, especially at the individual level.

12 In survival and transition models, the natural variation to be exploited is between individuals. Note that in a survival model, the dependent variable will change value only one time maximum (when an exit occurs), hence there is too little variation over time to warrant a fixed effects model. This also holds for our transition model from own-account worker to employer, as the dependent variable (measuring the occurrence of a transition) will only change value one time maximum over the estimation period.

13 In addition, although formal tests indicate that random effects is to be preferred over pooled ordinary regressions (available on request from the authors), the results of the two estimation methods are broadly similar, suggesting that unobserved heterogeneity is not a concern in our case.
} 
for many products. In other words, the use of tertiary education as the only proxy for a highly educated population, although defendable, might also be viewed as somewhat 'elitist'. Therefore, both proxies of higher education are considered in this study.

Our main explanatory variable is the share of the population holding tertiary education, observed per country (region) $j$ and year $t$ and derived from Eurostat. It is defined as the percentage of the active population from 25 to 64 years with at least first stage of tertiary education. It relates to the UNESCO International Standard Classification of Education (ISCED)-1997 categories 5 and 6, i.e., from the first stage of tertiary education and onwards. As we motivated earlier, an alternative to our main predictor described above is the percentage of the active population from 25 to 64 years with at least upper secondary education (i.e., ISCED-1997 categories 3 to 6).

Finally, as mentioned earlier, we also consider both these educational attainment indicators at the regional level (observed at NUTS-1 level). We note though that these regional data are of a somewhat lower quality than the education indicators at the country level, so that results need to be interpreted with care. First, the regional indicators were not available for all years so that we needed to estimate the data for the remaining years. Second, for four (mostly smaller) countries, regional data were not available. In these cases we included the country-level values. Third, the number of observations when using these education variables at the regional level is slightly smaller because for some regions there was a mismatch between the regional data offered by Eurostat and regions available in the ECHP data base. Further information about the regions included in the analysis is available in Table $\mathrm{C}$ in the Appendix.

\subsection{Control variables}

The empirical models include a set of explanatory variables at the individual (micro) level that are known to be associated with entrepreneurial performance (see Parker, 2009, and Millán et al., 2012, for overviews). Most importantly, we include the entrepreneur's education level in all performance equations. We distinguish secondary and tertiary education levels from primary education by means of a set of dummy variables. As discussed earlier, we expect a positive association between education and business performance.

In addition, the regression equations include common controls for gender (most previous studies observe significantly higher failure rates for female entrepreneurs, i.e., Boden and Nucci, 2000), age (the relation between age and persistence in entrepreneurship is often found to be non- 
linear), cohabiting status (associated with a lower likelihood of leaving entrepreneurship), the number of (young) children in the household (where the evidence of the effect on entrepreneurship duration is mixed), and relatives working as entrepreneurs. Moreover, we include (in some of the specifications underlying some of the robustness checks) a dummy variable which indicates whether an entrepreneur is active in an 'innovative' sector, i.e., a sector with above-average R\&Dintensity (we refer to Table A of the Appendix for the exact operationalization). Audretsch and Mahmood (1995) find that the exposure of new establishments to risk tends to be greater in highly innovative environments. We are particularly interested in the role of the interaction terms between this dummy and educational attainment at the macro level. Thus, entrepreneurs who are active in more innovative sectors may possibly benefit more from the availability of employees and consumers who are more highly educated. Finally, the impact of the duration of the spell (as entrepreneur or employer) on the exit probabilities is tested, as usual. These micro level variables are taken from or created by means of the ECHP. Their definitions and descriptive statistics are shown in the upper halves of Tables A and B in the Appendix, respectively.

Besides, we include several measures of macroeconomic conditions as controls in the analyses employing data on multiple countries and years. First, we include (the logarithm of real) GDP per capita. Insofar a higher level of economic development is associated with a labor force with higher entrepreneurial ability levels, GDP per capita may be associated positively with entrepreneurial performance. ${ }^{14}$ Second, we include the unemployment rate that varies per country and year. This variable may be negatively associated with entrepreneurial performance, as it increases necessity entrepreneurship and decreases opportunity entrepreneurship (Román et al., 2011, 2013; Thurik et al., 2008). Third, we include the variable Rule of Law. This variable describes the 'rules of the game' in societies, including rules relevant to entrepreneurs such as the extent of patent protection and intellectual property rights. ${ }^{15}$ These rules may improve the opportunities for (formal sector) entrepreneurship (Nyström, 2008) although the alternative, i.e., wage employment, may also become more attractive if a high 'Rule of Law' translates into an environment with better job

${ }^{14}$ While the level of GDP per capita may be seen as a measure of economic development, growth of GDP per capita may be seen as primarily capturing business cycle effects. We checked if the main results are sensitive to the inclusion of GDP per capita expressed in growth rates (besides the level of per capita GDP or instead of it). They are not.

15 The World Bank includes in this time-varying index several indicators that measure the extent to which agents have confidence in and abide by society's rules. These include perceptions of the incidence of crime, the effectiveness and predictability of the judiciary, and the enforceability of contracts. Together, these indicators measure the success of a society in developing an environment in which fair and predictable rules form the basis for economic and social interactions and, importantly, the extent to which property rights are protected (Kaufmann et al., 2009). 
security. Fourth, we include the share of services in the economy. ${ }^{16}$ As capital requirements in services are lower, a high share of services may favor entry into entrepreneurship, as well as exit, due to the positive correlation between entry and exit levels (Geroski, 1995).

Regarding data sources of the macro level variables, GDP per capita and standardized unemployment rates are taken from OECD sources. ${ }^{17}$ The variable Rule of Law is taken from the World Bank Worldwide Governance Indicators (WGI) data base (see Kaufmann et al., 2009), while the variable share of services is derived from OECD Labour Force Statistics. The educational attainment variables are taken from Eurostat. The definitions and descriptive statistics of these macro-variables are shown in the bottom halves of Tables A and B in the Appendix.

\section{Results}

The estimation results are presented in Tables 1 to 4, where each table corresponds to one of the four measures of entrepreneurial performance. All tables show the results from five model variants. Model (I) serves as a benchmark and only includes the explanatory variables at the micro level and those macroeconomic variables that serve as controls. Models (II) to (V) are used to test the hypothesis by means of our four different measures of educational attainment at the macro level: (i) tertiary education at the country level; (ii) at least upper secondary education at the country level; (iii) tertiary education at the regional level; and (iv) at least upper secondary education at the regional level. Each specification is presented in a two-column format, where marginal effects, expressed in relative terms (with respect to predicted values of dependent variables for sample means), and t-statistics are reported. ${ }^{18}$ We discuss the estimates for each of the outcome measures below in separate subsections. For each outcome variable, we first discuss results relating to our hypothesis, then we report results concerning individual education and finally we present the results regarding control variables. We conclude this section with a summary of these results.

\subsection{Entrepreneurship survival}

\footnotetext{
16 This variable measures the share of services (broadly defined) in total employment. It contains the sectors of Wholesale and retail trade, restaurants and hotels; Transport, storage and communication; Finance, insurance, real estate and business services; and Community, social and personal services.

${ }^{17}$ National Accounts and Main Economic Indicators; in case of missing data supplemented by information from OECD Labour Force Statistics.

${ }_{18}$ Multicollinearity is not a concern. The mean VIF is below 2 for all models. When using the 'collin' command in STATA we find that neither the tolerance nor the conditioning index raise any concerns.
} 
Table 1 presents the estimation results of the competing risk model for survival in entrepreneurship. The two risks considered are exit to paid-employment and exit to non-employment. To test our hypothesis, we consider models II to $\mathrm{V}$ and focus on the effect of the population's share of individuals with tertiary and/or secondary education in a specific country (region) and year. A higher share of highly educated individuals decreases the probabilities of switching to paidemployment, i.e., it increases survival chances of entrepreneurs when the first risk is considered. For both national and regional data, these results are considerably stronger when only including individuals with tertiary education in the definition of 'highly educated individuals' than when using a combination of tertiary and secondary education. The magnitude of the effects may be understood as follows. As an example, consider the effect of tertiary education in Model II. The marginal effect relative to the exit probability to paid employment (evaluated in the sample means of the independent variables) is -2.83 . Thus, an increase of 1 percentage point in the percentage of the active population holding tertiary education (for instance, from the sample mean $21 \%$ to $22 \%$ ) decreases the exit probability to paid employment with $2.83 \%$. Hence, as a result of such an impulse, the predicted exit probability to paid employment would change from 0.0998 (see second row of Table 1) to 0.0970 . As noted above, the effect in model III is somewhat weaker; an increase of 1 percent points in the percentage of the active population holding at least secondary education decreases the exit probability to paid employment with $0.9 \%$. When focusing on the second risk, i.e. exits to non-employment, national data also point to a positive effect of the share of highly educated individuals on survival chances. We thus conclude that our hypothesis is not rejected based on this first measure of entrepreneurial performance.

Regarding education at the individual level, entrepreneurs with secondary or tertiary level of education have lower chances to end up in unemployment or inactivity, compared to those with only primary education. When considering paid employment as an alternative, secondary education seems to increase the likelihood that an individual remains as entrepreneur whereas tertiary education does not seem to have any effect.

The control variables at the individual level paint the usual picture when considering nonemployment as the competing risk. Male entrepreneurs are less likely than females to switch to non-employment, while having young children makes it more difficult to run a business as it increases the chance to switch to non-employment. Having relatives working as entrepreneurs increases the chance of survival indicating that these relatives might transfer their entrepreneurial human capital or make their networks and other resources available. A less clear picture results 
when considering the effects of individual characteristics on the hazard of entrepreneurship relative to paid employment. As usual in hazard models for entrepreneurship, the duration dependence variable affects the probability of switching negatively. The longer someone is entrepreneur, the bigger the chance that he or she continues in this state.

We finally discuss the coefficients of the control variables at the country level. As expected, GDP per capita relates positively to the survival chances of entrepreneurs. Thus, in higher developed countries, entrepreneurs have higher survival chances, possibly because demand for new products and services is higher as a result of higher consumer wealth (Jackson, 1984). The negative association between the unemployment rate and entrepreneurship survival can be explained likewise: In countries with higher unemployment rates, circumstances to run businesses are less benign. The positive sign of the variable Rule of Law (i.e., negative impact on survival) suggests that in countries with narrowly defined 'rules of the game' entrepreneurship is less attractive (relative to paid employment). Sector structure also impacts entrepreneurship survival when exits to nonemployment are considered whereas exits to paid-employment are not affected.

-Insert Table 1 about here-

\subsection{Earnings of entrepreneurs}

Table 2 presents the estimation results of the entrepreneurial earnings equations. Our hypothesis is supported for both measures of education when using the national level data. It is also supported for the population's share holding at least upper secondary education when the regional data are considered. According to Model II in Table 2, an increase in the share of population holding tertiary education of 1 percent point would increase predicted earnings evaluated in the sample means of the independent variables with 3.9\%, corresponding to about 424 euros (1996 price level). In model III, a somewhat larger effect is obtained.

Concerning individual education, we observe that entrepreneurs with secondary or tertiary education have higher earnings compared to those holding only primary education. This is consistent with earlier studies that we discussed in Section 2.1.1.

Background variables associated with income levels are gender (female entrepreneurs earn less than male entrepreneurs) and age (nonlinear). Entrepreneurs with relatives working as entrepreneurs also have lower earnings (probably due to sharing the income from the same venture). Fi- 
nally, for the macro level controls we see that in high Rule of Law countries, self-employment earnings are lower (possibly due to fewer evasion possibilities, see Millan et al., 2012).

-Insert Table 2 about here-

\subsection{From own-account worker to employer}

Table 3 shows results for the outcome measure 'transitions from own-account worker to employer'. Concerning the role of educational attainment at the macro level, the result that stands out is the strong positive effect of the population's share holding tertiary education. As regards the magnitude of the effect, results for Model II imply that an increase of 1 percent points in the percentage of the active population holding tertiary education increases the predicted probability of switching from own-account worker to employer (evaluated in the sample means of the independent variables) with almost $6 \%$, from 0.1218 to 0.1290 . A weaker effect, however, is obtained in Model III, where the corresponding effect is about $2 \%$. Using this outcome measure, the data support our hypothesis once more.

The education level of the entrepreneur is an important determinant of switching from ownaccount worker status to the status of employer. Both secondary and tertiary education levels have a positive association with the likelihood of employing personnel.

The coefficients of the control variables at the individual level show that male entrepreneurs are more likely than females to employ personnel, cohabiting and the presence of relatives working as entrepreneurs are both associated with a higher likelihood of hiring employees. As for the macroeconomic control variables, Table 3 shows that the coefficients for per capita income vary across specifications. A negative relationship may be explained by the Lucas (1978) hypothesis: Higher per capita income implies higher wages and thus higher wage costs, whereas a positive relationship may indicate that economic circumstances are favorable to expand the business. The negative relationship with unemployment indicates that recessions are not a good time to start hiring personnel. The sign of Rule of Law is negative. Apparently when there are relatively many rules in society entrepreneurs are hesitant to hire people (and entrepreneurs may be inclined to become paid employee themselves, see Table 1). A big services sector is associated negatively with transitions to employership. This may reflect the smaller scale of operations in services, reducing the need to hire personnel.

-Insert Table 3 about here- 


\subsection{Employership survival}

Table 4 presents the results for survival in employership. This exercise uses the subsample of those entering employership from own-account work within the sample period 1994-2001. Also for this performance measure, the results are consistent with a positive effect of the population's share holding higher education on individual performance. Model II implies that an increase of 1 percent point in the percentage of the active population holding tertiary education decreases the predicted probability of exiting employership (evaluated in the sample means of the independent variables) with $2.3 \%$, from 0.1864 to 0.1821 . Again, this effect is stronger than that obtained for the percentage of the active population holding at least secondary education in Model III; that negative effect is only $1.3 \%$.

Concerning educational attainment at the micro level, our results show that employers with higher levels of education, both (upper) secondary and tertiary, are more likely to survive as employers.

For the individual controls, male employers have a higher likelihood to survive as employers than females, and entrepreneurs with relatives working as entrepreneurs have higher probabilities of surviving in employership. Concerning macro-level variables, per capita income has a negative sign suggesting that in higher developed countries it is easier for employers to continue employing personnel. Unemployment has a positive sign indicating that in times of recession jobs are lost and hence that some employers can no longer provide jobs for their employees. Consistent with results in the other tables, Rule of Law decreases survival chances.

- Insert Table 4 about here -

\subsection{Summary of the main results}

The main results from Tables 1 to 4 can be summarized as follows. A population's share of highly educated individuals has a positive impact on all measures of individual entrepreneurship performance: It increases survival chances of entrepreneurs in general and employers in particular, while the impact on the probability of own-account workers to start employing personnel is particularly strong. Besides, entrepreneurs in countries (regions) with higher educated populations enjoy higher earnings. The results are similar when using regional education data to these obtained using national education data. Most of our analyses indicate that in modern (EU-15) economies it is particularly tertiary education that feeds the environment in which entrepreneurs flour- 
ish. However, for earnings we find that both (upper) secondary and tertiary education contribute to higher earnings of individual entrepreneurs. The above-mentioned results for education at the macro level are independent of and additional to those for the education level of the entrepreneurs themselves.

\subsection{Robustness checks}

We perform a couple of robustness checks. First, as indicated in footnotes 6 and 14, the results are independent of the definition of parttime work and the way GDP per capita is included in the models (level or growth rate). Second, we assess to what extent the result hinges on the innovativeness of the sector in which the entrepreneur is active. We find that the impact of a higher tertiary educational attainment rate on entrepreneurial performance is not stronger for entrepreneurs who are active in R\&D-intense sectors (see Table A in the Appendix for the definition) than for other entrepreneurs. ${ }^{19}$ A possible explanation is that R\&D-intensity in services may be underestimated in our sample (only 11\% of innovative country-sector combinations in our sample are in services), consistent with the observation that R\&D surveys tend to underrepresent the innovative activities of service firms (Miles, 2005). Hence, when comparing innovativeness in manufacturing and services sectors, R\&D may not be a good measure to use. As a third robustness check we replace the continuous 'job tenure in entrepreneurship (or employership) status' with a set of dummy variables where tenure in the current status of one year is the benchmark. We find increasingly negative coefficients indicating that the effect of tenure indeed increases the likelihood of survival monotonously. Fourth, using enrollment rates in secondary or tertiary education (instead of educational attainment levels of the active population), taken from the World Bank's EdStats data set, we find similar results as those presented in Tables 1-4.

\section{Conclusion}

Human capital obtained through education has been shown to be one of the strongest drivers of entrepreneurship performance, irrespective of the measure of the entrepreneur's performance. However, the human capital of the entrepreneur herself is only one of the inputs into the production process of her venture. The entrepreneur's performance is also likely to be affected by the education level of the possible stakeholders in the entrepreneur's venture, such as consumers and employees. Employees with higher levels of education may be more productive whereas consumers with higher education levels increase the demand for product variety as well as for innovative

\footnotetext{
${ }^{19}$ In particular, interaction terms between tertiary educational attainment and the innovative sector dummy are not significant.
} 
products and services. As a consequence, new (niche) business opportunities will likely emerge and entrepreneurial firms are likely to benefit from these.

Measuring these effects of more highly educated employees and consumers is difficult, however. One should employ a research method that takes into account that the effects described may be indistinguishable from effects of selectivity. More highly educated employees will not only be more productive but they will also sort into businesses that value them more highly due to their higher contribution to productivity. The attraction of consumers to specific firms is also nonrandom and guided by selectivity. The solution is to find exogenous variation in the accessibility of highly educated individuals as workers and consumers to firms. We therefore studied the effects of the share of highly educated individuals within a region on the business performance of ventures in that region. We developed and empirically tested the following hypothesis: The performance of an entrepreneur is not only affected positively by ber own education level but in addition, also by the share of highly educated individuals in the (local) population. The hypothesis is tested using several measures of individual entrepreneurship success: survival as an entrepreneur, earnings, the probability of employing personnel and the survival as an employer.

The main limitation of our study is that we cannot assess the relative strengths of the distinct channels through which a highly educated population may affect an individual's entrepreneurship success (i.e., a higher quality working population and a more sophisticated consumer market). Furthermore, although our dataset enables us to investigate several measures of individual entrepreneurship success, it does not allow us to investigate the relation between a country's or region's education level and the general ability of entrepreneurs to create jobs (we only consider hiring decisions of those entrepreneurs with no employees). This might be a topic for future research.

We find support for a positive relationship between higher (primarily tertiary) educational attainment levels of the (local) population and all measures of an individual's entrepreneurship success considered in our study: survival, earnings and job creation by own-account workers. To the extent that our results also extend to job creation by entrepreneurs in general, it is likely that countries or regions with a more highly educated population will have fewer but bigger firms (as the average entrepreneur in such environments creates more jobs), consistent with Van Praag and Van Stel (2013). These authors find, for a sample of OECD countries, that the 'optimal' business ownership rate (optimal in terms of macroeconomic performance) is a decreasing function of the 
enrollment rate in tertiary education. In the spirit of the classic contribution by Lucas (1978), the authors explain this result using microeconomic theory of occupational choice between entrepreneurship (business ownership) and wage-employment. The higher enrollment rates lead to more people with higher 'entrepreneurial ability' levels for whom it is optimal to run larger firms with more employees if they choose to become entrepreneurs.

The results of the current study show that the average entrepreneur is more successful in countries or regions with higher levels of education consistent with Lucas (1978) and Van Praag and Van Stel (2013). Entrepreneurs in such environments do not only run larger firms, they also require more highly qualified personnel. In countries or regions with more highly educated individuals, the supply of such highly qualified workers is amply available so that demand and supply for highly qualified workers is easily met.

The policy implication is that the education level of the population can be viewed and used as a direct instrument to develop high-quality entrepreneurship irrespective of the labor market choices that these educated people make (i.e., entrepreneurship versus wage employment). Those higher educated individuals with the highest entrepreneurial ability levels will select into entrepreneurship and require big numbers of highly qualified employees for their firms. Those highly educated individuals who do not select into entrepreneurship but instead become employees, contribute positively to high-quality entrepreneurship by supplying their high-quality labor.

In most developed countries participation rates in tertiary education are increasing over time. Moreover, entrepreneurship education in institutions of higher education is also becoming more and more common. Thus, as is suggested by the results of our paper and those of Van Praag and Van Stel (2013), individuals selecting into entrepreneurship will have even higher entrepreneurial ability levels, and, accordingly, will run even larger firms. The number of entrepreneurs will tend to be lower whereas the number of people employed in entrepreneurial firms will be higher and of higher quality. Programs of entrepreneurship education in institutions of higher education should aim at reaching a broader audience. They should not only be attractive to (the probably declining numbers of) future entrepreneurs, but also to the increasing numbers of future employees in entrepreneurial firms. It is likely that for many students the increased entrepreneurial skills resulting from entrepreneurship curricula will be beneficial in their career in the wage sector, where entrepreneurial employees (i.e., intrapreneurs) form an ever more important asset of successful firms (Bosma et al., 2010). 
To summarize, we obtain evidence that the population distribution of higher education is a driver of individual entrepreneurship performance. Thus, educational policies may be viewed as an additional instrument to develop high-quality entrepreneurial businesses. In particular, an education system that results in a higher share of people with tertiary education levels will produce more productive entrepreneurs together with more productive employees where the latter will benefit the former and vice versa. 


\section{References}

Acs, Z.J. and C. Armington (2004), The impact of geographic differences in human capital on service firm formation rates, Journal of Urban Economics 56(2), 244-278.

Aldrich, H.E. and E. Auster (1986), Even dwarfs started small: Liabilities of size and age and their strategic implications. In: B.M. Staw and L.L. Cummings (Eds.), Research in Organizational Behavior, 8, Greenwich, CT: JAI Press, 165-198.

Amemiya, T. (1981), Qualitative response models: A survey, Journal of Economic Literature 19(4), 1483-1536.

Ashenfelter, O., C. Harmon and H. Oosterbeek (1999), A review of estimates of the schooling/earnings relationship, with tests for publication bias, Labour Economics 6(4), 453-470.

Astley, W.G. (1985), The two ecologies: Population and community perspectives on organizational evolution, Administrative Science Quarterly 30(2), 224-241.

Audretsch, D.B. and T. Mahmood (1995), New firm survival: new results using a hazard function, Review of Economics and Statistics 77(1), 97-103.

Backes-Gellner, U. and A. Werner (2007), Entrepreneurial signalling via education: A success factor in innovative start-ups, Small Business Economics 29(1), 173-190.

Barber, A., M. Wesson, Q. Roberson and S. Taylor (1999), A tale of two job markets: organizational size and its side effects on hiring practices and job search behavior, Personnel Psychology 52(4), 841-867.

Barney J.B. (1991), Firm resources and sustained competitive advantage, Journal of Management 17(1), 99-120.

Barney, J.B. and P.M. Wright (1998), On becoming a strategic partner: The role of human resources in gaining competitive advantage, Human Resource Management 37(1), 31-46.

Bates, T. (1990), Entrepreneur human capital inputs and small business longevity, Review of Economics and Statistics 72(4), 551-559.

Becker, G. (1964), Human Capital: A theoretical and empirical analysis with special reference to education, Chicago: University of Chicago Press ( $3^{\text {rd }}$ edition, 1993).

Benn, J. (2004), Consumer education between 'consumership' and citizenship: experiences from studies of young people, International Journal of Consumer Studies 28(2), 108-116.

Benz, M. and B.S. Frey (2008), Being independent is a great thing: subjective evaluations of self-employment and hierarchy, Economica 75(298), 362-383.

Bishop, J.H. (1994), The impact of previous training on productivity and wages. In L. Lynch (Ed.), Training and the Private Sector: International Comparisons, Chicago: University of Chicago Press, 161-200.

Bloom, P.E. and P. Kotler (1975), Strategies for high market-share companies, Harvard Business Review 53(6), 63-72.

Blundell, R., L. Dearden, C. Meguir and B. Sianesi (1999), Human capital investment: The returns from education and training to the individual, the firm and the economy, Fiscal Studies 20(1), 1-23.

Boden, R.J. and A.R. Nucci (2000), On the survival prospects of men's and women's new business ventures, Journal of Business Venturing 15(4), 347-362.

Bosma, N., E. Stam and S. Wennekers (2010), Intrapreneurship - An international study, EIM Research Report H201005, Zoetermeer, The Netherlands: Panteia/EIM.

Brown, C. and J. Medoff (1989), The Employer Size-Wage Effect, Journal of Political Economy 97(5), 1027-1059. 
Buenstorf, G. (2003), Designing clunkers: Demand-side innovation and the early history of the mountain bike. In: J.S. Metcalfe and U. Cantner (Eds.), Change, Transformation and Development. Heidelberg: Physica, 53-70.

Burke, A.E., F.R. FitzRoy and M.A. Nolan (2000), When Less is More: Distinguishing Between Entrepreneurial Choice and Performance, Oxford Bulletin of Economics and Statistics 62(5), 565-587.

Calvo, G.A. and S. Wellisz (1980), Technology, entrepreneurs, and firm size, Quarterly Journal of Economics 95(4), 663677.

Carroll, M., M. Marchington, J. Earnshaw and S. Taylor (1999), Recruitment in small firms: processes, methods and problems, Employee Relations 21(3), 236-250.

Caves, R.E. and M.E. Porter (1977), From entry barriers to mobility barriers, Quarterly Journal of Economics 91(2), 241261.

Chen, M.J. and D.C. Hambrick (1995), Speed, stealth, and selective attack: how small firms differ from large firms in competitive behavior, Academy of Management Journal 38(2), 453-482.

Cheng, S. and J.S. Long (2007), Testing for IIA in the multinomial logit model, Sociological Methods and Research 35(4), 583-600.

Clark, A.E. (1996), Job satisfaction in Britain, British Journal of Industrial Relations 34(2), 189-217.

Cooper, A.C., F.J. Gimeno-Gascon and C.Y. Woo (1994), Initial human and financial capital as predictors of new venture performance, Journal of Business Venturing 9(5), 371-395.

Cooper, A.C., G.E. Willard and C.Y. Woo (1986), Strategies of high-performing new and small firms: A reexamination of the niche concept, Journal of Business Venturing, 1(3), 247-260.

Cunha, F. and J. Heckman (2010), Investing in our young people, NBER Working Paper w16201, Cambridge, MA: National Bureau of Economic Research.

Czarnitzki, D. and H. Hottenrott (2009), Are local milieus the key to innovation performance?, Journal of Regional Science 49(1), 81-112.

Davidsson, P. and B. Honig (2003), The role of social and human capital among nascent entrepreneurs, Journal of Business Venturing 18(3), 301-331.

Dean, T.J., R.L. Brown and C.E. Bamford (1998), Differences in large and small firm responses to environmental context: Strategic implications from a comparative analysis of business formations, Strategic Management Journal 19(8), 709-728.

Dean, T.J. and G.D. Meyer (1996), Industry environments and new venture formations in U.S. manufacturing: A conceptual and empirical analysis of demand determinants, Journal of Business Venturing 11(2), 107-132.

Deshpande, S. and D. Golhar (1994), HRM practices in large and small manufacturing firms: a comparative study, Journal of Small Business Management 32(2), 49-56.

Doms, M., E. Lewis and A. Robb (2010), Local labor force education, new business characteristics, and firm performance, Journal of Urban Economics 67(1), 61-77.

Elfenbein, D.W., B.H. Hamilton and T. Zenger (2010), The small firm effect and the entrepreneurial spawning of scientists and engineers, Management Science 56(4), 659-681.

Fairlie, R.W. and A.M. Robb (2007), Families, human capital, and small business: evidence from the Characteristics of Business Owners Survey, Industrial and Labor Relations Review 60(2), 225-245.

Fombrun, C. and M. Shanley (1990), What's in a name? Reputation building and corporate strategy, Academy of Management Journal 33(2), 233-258. 
Galbraith, J.R. (1977), Organization Design. Reading, MA: Addison-Wesley.

García-Serrano, C. (2011), Does size matter? The influence of firm size on working conditions, job satisfaction and quit intentions, Scottish Journal of Policitical Economy 58(2), 221-247.

Gartner, W.B. and S. Shane (1995). Measuring entrepreneurship over time, Journal of Business Venturing 10(4), $283-301$.

Gennaioli, N., R. La Porta, F. Lopez-de-Silanes and A. Shleifer (2013), Human capital and regional development, Quarterly Journal of Economics 128(1), 105-164.

Geroski, P. (1995), What do we know about entry?, International Journal of Industrial Organization 13(4), 421-441.

Geroski, P.A., J. Mata and P. Portugal (2010), Founding conditions and the survival of new firms, Strategic Management Journal 31(5), 510-529.

Ghemawat, P. (1991), Market incumbency and technological inertia, Marketing Science 10(2), 161-171.

Greene, W. (2004), The behaviour of the maximum likelihood estimator of limited dependent variable models in the presence of fixed effects, Econometrics Journal 7(1), 98-119.

Haltiwanger, J.C., J.I. Lane and J.R. Spletzer (1999), Productivity Differences across Employers: The Roles of Employer Size, Age, and Human Capital, American Economic Review 89(2), Papers and Proceedings, 94-98.

Hanushek, E. and L. Woessmann (2008), The role of cognitive skills in economic development, Journal of Economic Literature 46(3), 607-668.

Haveman, H.A. and L. Nonnemaker (2000), Competition in multiple geographic markets: The Impact on growth and market entry, Administrative Science Quarterly 45(2), 232-267.

Henley, A. (2005), Job creation by the self-employed: the roles of entrepreneurial and financial capital, Small Business Economics 25(2), 175-196.

Hitt, M.A., R.E. Hoskisson and R.D. Ireland (1990), Mergers and acquisitions and managerial commitment to innovation in M-form firms, Strategic Management Journal 11(1), 29-47.

Hollister, M.N. (2004), Does firm size matter anymore? The new economy and firm size wage effects, American Sociological Review 69(5), 659-676.

Idson, T.L. (1990), Establishment size, job satisfaction and the structure of work, Applied Economics 22(8), 1007-1018.

Jackson, L.F. (1984), Hierarchic Demand and the Engel Curve for Variety, Review of Economics and Statistics 66(1), 815.

Katz, R.L. (1970), Cases and concepts in corporate strategy, Englewood Cliffs, NJ: Prentice-Hall.

Kaufmann, D., A. Kraay and M. Mastruzzi (2009). Governance Matters VIII: Aggregate and Individual Governance Indicators 1996-2008, World Bank Policy Research, Working Paper No. 4978, Washington, DC: World Bank.

Kim, W.Ch. and R. Mauborgne (2005). Blue Ocean Strategy: How to Create Uncontested Market Space and Make the Competition Irrelevant, Boston, MA: Harvard Business School Press.

Lee, K.S., G.H. Lim and S.J. Tan (1999), Dealing with resource disadvantage: Generic strategies for SMEs, Small Business Economics 12(4), 299-311.

Lester, R.A. (1967), Pay differentials by size of firm, Industrial Relations 7(1), 57-67.

Long J.S. and J. Freese (2006), Regression Models for Categorical Dependent Variables using Stata, Second Ed. Stata Press, College Station, TX.

Lucas, R.E. (1978), On the size distribution of business firms, Bell Journal of Economics 9(2), 508-523.

Masters, S.H. (1969), Wages and plant size: An interindustry analysis, Review of Economics and Statistics 51(3), 341-345. 
McFadden, D. (1974), Conditional logit analysis of qualitative choice behaviour. In P. Zarembka (Ed.), Frontiers in econometrics. New York: Academic Press, 105-142.

Miles, I. (2005), Innovation in services. In J. Fagerberg, D.C. Mowery and R.R. Nelson (Eds.), The Oxford Handbook of Innovation, Oxford, UK: Oxford University Press, 433-458.

Millán, A., J.M. Millán, C. Román and A.J. van Stel (2013), How does employment protection legislation influence hiring and firing decisions by the smallest firms? Economics Letters, forthcoming.

Millán, J.M., E. Congregado and C. Román (2012), Determinants of self-employment survival in Europe, Small Business Economics 38(2), 231-258.

Millán, J.M., J. Hessels, R. Thurik and R. Aguado (2013), Determinants of job satisfaction: A European comparison of self-employed and paid employees, Small Business Economics, forthcoming. DOI: 10.1007/s11187-011-9380-1.

Mincer, J. (1958), Investment in human capital and personal income distribution, Journal of Political Economy 66(4), 281-302.

Mintzberg, H. (1979), The structuring of organizations. Englewood Cliffs, NJ: Prentice-Hall.

Nooteboom, B. (1994), Innovation and diffusion in small firms: Theory and evidence, Small Business Economics 6(5), 327-347.

Nyström, K. (2008), The institutions of economic freedom and entrepreneurship: Evidence from Panel Data, Public Choice 136(3-4), 269-282.

Oi, W.Y. and T.L. Idson (1999), Firm size and wages. In: O. Ashenfelter and D. Card (Eds.), Handbook of Labor Economics 3(B), Amsterdam, Netherlands: North Holland, 2165-2214.

Parker, S.C. and C.M. van Praag (2006), Schooling, capital constraints and entrepreneurial performance: The endogenous triangle, Journal of Business and Economic Statistics 24(4), 416-431.

Parker, S.C. (2009), The Economics of Entrepreneurship, Cambridge, UK: Cambridge University Press.

Peracchi, F. (2002), The European Community Household Panel: A Review, Empirical Economics 27(1), 63-90.

Porter, M.E. (1979), The structure within industries and companies' performance, Review of Economics and Statistics 61(2), 214-227.

Robinson, P.B. and E.A. Sexton (1994), The effect of education and experience on self-employment success, Journal of Business Venturing 9(2), 141-156.

Román, C., E. Congregado and J.M. Millán (2011), Dependent self-employment as a way to evade employment protection legislation, Small Business Economics 37(3), 363-392.

Román, C., E. Congregado and J.M. Millán (2013), Start-up incentives: entrepreneurship policy or active labour market programme? Journal of Business Venturing 28(1), 151-175.

Scherer, F.M. (1976), Industrial structure, scale economies and worker alienation. In: R.T. Masson and P.D. Qualls (Eds.), Essays on Industrial Organization in Honour of Joe S. Bain. Cambridge, MA: Ballinger, 105-122.

Scherer, F.M. (1980), Industrial market structure and economic performance, Chicago: Rand McNally.

Schmidt, C.M. and K.F. Zimmermann (1991), Work Characteristics, Firm Size and Wages, Review of Economics and Statistics 73(4), 705-710.

Shane, S. (2009), Why encouraging more people to become entrepreneurs is bad public policy, Small Business Economics 33(2), 141-149.

Singh, J.V. (1990), Organizational evolution, Beverly Hills, CA: Sage. 
Smith, K.G., C.M. Grimm,. M.J. Gannon and M.J. Chen (1991), Organizational information processing, competitive responses, and performance in the U.S. domestic airline industry. Academy of Management Journal 34(1), 60-85.

Spence, A. (1973), Job market signaling, Quarterly Journal of Economics 87(3), 355-374.

Sternberg, R. and S. Wennekers (2005), Determinants and effects of new business creation; investigations using Global Entrepreneurship Monitor data, Small Business Economics 24(3), 193-203.

Subramaniam, M. and Youndt, M.A. (2005), The influence of intellectual capital on the types of innovative capabilities. Academy of Management Journal 48(3), 450-463.

Tanova, C. (2003), Firm size and recruitment: staffing practices in small and large organizations in north Cyprus, Career Development International 8(2), 107-114.

Thurik, A.R., M.A. Carree, A.J. van Stel and D.B. Audretsch (2008), Does self-employment reduce unemployment?, Journal of Business Venturing 23(6), 673-686.

Toole, A. and D. Czarnitzki (2009), Exploring the relationship between scientist human capital and firm performance: The case of biomedical academic entrepreneurs in the SBIR Program, Management Science 55(1), 101-114.

Unger J., A. Rauch, M. Frese and N. Rosenbusch (2011), Human capital and entrepreneurial success: A metaanalytical review, Journal of Business Venturing 26(3), 341-358.

Van der Sluis, J., C.M. Van Praag and W. Vijverberg (2008), Education and entrepreneurship selection and performance: A review of the empirical literature, Journal of Economic Surveys 22(5), 795-841.

Van Praag, C.M. (2005), Successful Entrepreneurship, Cheltenham, UK: Edward Elgar.

Van Praag, C.M. and A.J. van Stel (2013), The more business owners, the merrier? The role of tertiary education, Small Business Economics 41(2), 335-357.

Van Praag, C.M. and P.H. Versloot (2008), The economic benefits and costs of entrepreneurship: A review of the research, Foundations and Trends in Entrepreneurship 4 (2), 65-154.

Van Praag, C.M., A. van Witteloostuijn and J. van der Sluis (2013), The higher returns to formal education for entrepreneurs versus employees, Small Business Economics 40(2), 375-396.

Van Praag, C.M., G. van Dijk, G. de Wit and M. Pasaribu (2009), Waarom groeien sommige bedrijven sneller dan andere? [Why do some firms grow faster than others?], ACE Entrepreneurship Update 7, Amsterdam Center for Entrepreneurship, University of Amsterdam.

Vandenbussche, J., P. Aghion and C. Meghir (2006), Growth, distance to frontier and composition of human capital, Journal of Economic Growth 11(2), 97-127.

Weick, K. (1996), Drop your tools: An allegory for organizational studies, Administrative Science Quarterly 41(2), 301313.

Wennekers, S., A.J. van Stel, M. Carree and R. Thurik (2010), The relationship between entrepreneurship and economic development: Is it U-shaped?, Foundations and Trends in Entrepreneurship 6(3), 167-237.

Wernerfelt, B. (1984), The Resource-Based View of the Firm, Strategic Management Journal 5(2), 171-180.

Witt, U. (2001), Learning to consume- a theory of wants and the growth of demand, Journal of Evolutionary Economics 11(1), 23-36.

Wooldridge, J. (2002), Econometric Analysis of Cross Section and Panel Data, Cambridge, MA: MIT Press. 
Table 1. Survival model: Departure from entrepreneurship

-Competing risk model: Exits to paid-employment vs. Exits to unemployment and inactivity-

\begin{tabular}{|c|c|c|c|c|c|c|c|c|c|c|c|c|c|c|c|c|c|}
\hline \multirow[b]{2}{*}{ Final state } & \multicolumn{3}{|c|}{ Model I } & \multicolumn{3}{|c|}{ Model II } & \multicolumn{4}{|c|}{ Model III } & \multicolumn{4}{|c|}{ Model IV } & \multicolumn{3}{|c|}{ Model V } \\
\hline & Paid employment & $\begin{array}{c}\text { Unen } \\
\text { and }\end{array}$ & $\begin{array}{l}\text { yment } \\
\text { tivity }\end{array}$ & Paid employment & $\begin{array}{r}\text { Une } \\
\text { and }\end{array}$ & $\begin{array}{l}\text { yyment } \\
\text { ctivity }\end{array}$ & Paid er & oyment & $\begin{array}{c}\text { Unen } \\
\text { and }\end{array}$ & $\begin{array}{l}\text { yment } \\
\text { tivity }\end{array}$ & Paid en & oyment & $\begin{array}{l}\text { Unen } \\
\text { and }\end{array}$ & $\begin{array}{l}\text { yment } \\
\text { tivity }\end{array}$ & Paid er & oyment & $\begin{array}{l}\text { Unemployment } \\
\text { and inactivity }\end{array}$ \\
\hline Predicted probability $(y)$ & 0.1002 & & & 0.0998 & & & & & & & & & & & & & 0.0423 \\
\hline Independent variables $(x)$ & $\frac{d y / d x}{y} \%{ }^{a}$ & $\frac{d y / d x}{y} \%{ }^{2}$ & t-stat. & $\frac{d y / d x}{y} \%^{a}$ & $\frac{d y / d x}{y} \%$ & t-stat. & $\frac{d y / d x}{y} \%$ & t-stat. & $\frac{d y / d x}{y} \%$ & t-stat. & $\frac{d y / d x}{y} \%{ }^{a}$ & t-stat. & $\frac{d y / d x}{y} \%$ & t-stat. & $\frac{d y / d x}{y} \%$ & t-stat. & $\frac{d y / d x}{y} \%{ }^{a}$ \\
\hline
\end{tabular}

Educational attainment (macro level)

Tertiary (ISCED 97 5-6) (\%; national data)

Secondary + Tertiary (ISCED $973-6)(\%$; national data)

Tertiary (ISCED97 5-6) (\%; regional data)

$-2.83-5.00^{* * *} \quad-4.51 \quad-5.20 * * *$

Secondary + Tertiary (ISCED 97 3-6) (\%; regional data)

$-0.90-4.45 * * * \quad-0.42 \quad-1.32$

Educational attainment (micro level)

Basic education $\mathrm{b}(r e$.

Secondary education

Tertiary education ${ }^{b}$

$\begin{array}{llllllll}-12.38 & -2.08 * * & -21.39 & -2.75 * * * & -11.06 & -1.84 * & -18.95 & -2.39 * *\end{array}$

Demographics

Femate

Age (18-65)

Age (squared)

Cohabiting

\begin{tabular}{|c|c|c|c|c|c|c|c|c|c|c|c|c|c|}
\hline-7.68 & -1.45 & 152.40 & $13.86^{* * *}$ & -7.93 & -1.50 & 152.11 & $13.71 * * *$ & -7.70 & -1.46 & 152.52 & $13.84 * * *$ & -6.25 & -1.15 \\
\hline-0.90 & -0.39 & -22.84 & $-8.06 * * *$ & -0.58 & -0.26 & -22.51 & $-7.87 * * *$ & -0.27 & -0.12 & -22.80 & $-7.97 * * *$ & -1.44 & -0.63 \\
\hline E-03 & 0.13 & 0.24 & $9.20 * * *$ & $-4.1 \mathrm{E}-05$ & 0.00 & 0.31 & $9.00 * * *$ & $-3.4 \mathrm{E}-03$ & -0.12 & 0.32 & $9.10 * * *$ & $1.2 \mathrm{E}-02$ & 0.41 \\
\hline 18.06 & $-2.51 * *$ & -15.87 & -1.60 & -16.63 & $-2.31 * *$ & -13.95 & -1.41 & -17.48 & $-2.44 * *$ & -15.15 & -1.52 & -17.94 & $-2.42 * *$ \\
\hline 0.80 & 0.28 & 17.79 & $4.16^{* * *}$ & 0.80 & 0.27 & 17.42 & $4.04 * * *$ & 0.89 & 0.30 & 17.74 & $4.13 * * *$ & 0.57 & 0.18 \\
\hline & $-3.81 * * *$ & -18.75 & $-2.58 * * *$ & -20.33 & $-3.70 * * *$ & -18.13 & $-2.49 * *$ & -22.22 & $-4.06 * * *$ & -19.40 & $-2.69 * * *$ & -22.56 & $-4.00^{*}$ \\
\hline
\end{tabular}

$149.0513 .36 * * *$

$-2222-4.06 * * *$

$-19.40-2.69 * * *$

$22.56-4.00^{* * *}$

$\begin{array}{rrrrrr}-23.03 & -7.91 * * * & -1.38 & -0.61 & -23.08 & -7.93 * * *\end{array}$

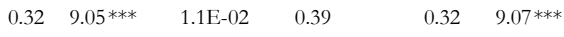

$\begin{array}{llllll}-14.41 & -1.43 & -18.11 & -2.45 * * & -14.33 & -1.43\end{array}$

Duration dependence

Job tenure as entrepreneur (in $\log s)$

$\begin{array}{llllllll}-77.84 & -16.46^{* * *} & -103.37 & -14.72^{* * *} & -73.47 & -15.24 * * * & -95.93 & -13.14 * * *\end{array}$

$-76.43-16.10^{* * *}$

$-102.61-14.60 * * *$

$-78.26-15.96 * * *$

$\begin{array}{ll}-40 & 3.70 * * *\end{array}$

$0.61 \quad 0.20$

$\begin{array}{rr}-14.33 & -1.43 \\ 16.68 & 3.77 * * *\end{array}$

Macroeconomic variables

GDP per capita (in logs)

Unemployment rate (\%)

Rule of law (from -2.5 to 2.5)

$\begin{array}{rrrlrrrl}-44.51 & -4.29 * * * & -5.77 & -0.42 & -54.78 & -5.29 * * * & -26.55 & -1.91 * \\ 2.50 & 3.30 * * * & 7.93 & 7.63 * * * & 4.52 & 5.50 * * * & 10.78 & 9.21 * * * \\ 50.30 & 5.61 * * * & 1.44 & 0.13 & 97.14 & 7.97 * * * & 74.07 & 4.20 * * *\end{array}$

$\begin{array}{rr}-30.57 & -2.79 * * *\end{array}$

$\begin{array}{rr}-0.20 & -0.01\end{array}$

$8.05 \quad 7.75 * * *$

$\begin{array}{rr}-50.65 & -4.70 * * * \\ 3.17 & 4.04 * *\end{array}$

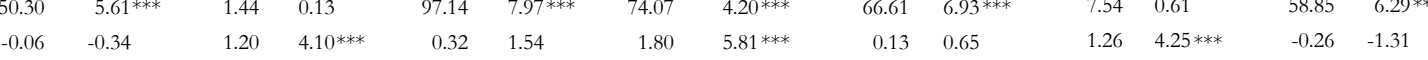

Number of observations

Number of spells

Number of censored spells

Number of completed spells

Log pseudolikelihood

13,676
6,342

13,676
6,342

4.10

13,676

$0.13-0.65$

$\begin{array}{lllll}-104.80-14.58 * * * & -78.70 & -16.09 * * * & -104.93 & -14.64 * * *\end{array}$

Notes: a For continuous va inb

1,505

3,962

${ }^{b}$ Dummy variable
$* 0.1>p \geq 0.05 ; * 0.05>p \geq 0.01 ; * * * p<0.01$.

$-7,245.3$

885

1,505

6,342

$\begin{array}{llr}13,676 & & 12,904 \\ 6,342 & & 5,967 \\ 3,962 & & 3,706 \\ & 885 & 1,419\end{array}$

$\begin{array}{llllll}-4.50 & -0.32 & -45.67 & -4.33 * * * & -4.61 & -0.33\end{array}$

$\begin{array}{rrrrrr}8.22 & 7.41 * * * & 2.68 & 3.60 * * * & 8.37 & 7.85 * * *\end{array}$

$\begin{array}{llllll}8.11 & 0.66 & 52.15 & 5.52 * * * & 12.07 & 0.99\end{array}$

$\begin{array}{llllll}1.01 & 3.51 * * * & -0.30 & -1.46 & 1.09 & 3.77 * * *\end{array}$ 
Table 2. Earnings as self-employed (tobit estimations)

\begin{tabular}{|c|c|c|c|c|c|c|c|c|c|c|}
\hline \multirow[b]{2}{*}{ Independent variables $(x)$} & \multicolumn{2}{|c|}{ Model I } & \multicolumn{2}{|c|}{ Model II } & \multicolumn{2}{|c|}{ Model III } & \multicolumn{2}{|c|}{ Model IV } & \multicolumn{2}{|c|}{ Model V } \\
\hline & $\mathrm{dy} / \mathrm{dx} \mathrm{a}^{\mathrm{a}}$ & t-stat. & $\mathrm{dy} / \mathrm{dx}$ a & t-stat. & $\mathrm{dy} / \mathrm{dx}$ a & t-stat. & $\mathrm{dy} / \mathrm{dx}$ a & t-stat. & $\mathrm{dy} / \mathrm{dx}$ a & t-stat. \\
\hline \multicolumn{11}{|l|}{ Educational attainment (macro level) } \\
\hline Tertiary (ISCED97 5-6) (\%; national data) & & & 0.039 & $2.96 * * *$ & & & & & & \\
\hline Secondary + Tertiary (ISCED $973-6)(\%$; national data) & & & & & 0.050 & $9.87 * * *$ & & & & \\
\hline Tertiary (ISCED 97 5-6) (\%; regional data) & & & & & & & 0.009 & 1.31 & & \\
\hline Secondary + Tertiary (ISCED $973-6)(\%$; regional data) & & & & & & & & & 0.015 & $5.49 * * *$ \\
\hline \multicolumn{11}{|l|}{ Educational attainment (micro level) } \\
\hline \multicolumn{11}{|l|}{ Basic education $\mathrm{b}(r e f)$} \\
\hline Secondary education $\mathrm{b}$ & 0.50 & $3.88^{* * *}$ & 0.48 & $3.78 * * *$ & 0.21 & 1.61 & 0.48 & $3.70 * * *$ & 0.41 & $3.19 * * *$ \\
\hline Tertiary education $\mathrm{b}$ & 0.47 & $3.04^{* * *}$ & 0.41 & $2.67 * * *$ & 0.22 & 1.42 & 0.57 & $3.69 * * *$ & 0.47 & $3.05 * * *$ \\
\hline \multicolumn{11}{|l|}{ Demographics } \\
\hline Female b & -1.42 & $-10.06 * * *$ & -1.41 & $-10.03 * * *$ & -1.41 & $-10.16 * * *$ & -1.53 & $-10.92 * * *$ & -1.53 & $-10.97 * * *$ \\
\hline Age (18-65) & 0.27 & $4.87 * * *$ & 0.26 & $4.71 * * *$ & 0.22 & $4.10 * * *$ & 0.26 & $4.72 * * *$ & 0.25 & $4.59 * * *$ \\
\hline Age (squared) & $-3.1 \mathrm{E}-03$ & $-4.58 * * *$ & $-3.0 \mathrm{E}-03$ & $-4.45 * * *$ & $-2.6 \mathrm{E}-03$ & $-3.88 * * *$ & $-2.9 \mathrm{E}-03$ & $-4.35 * * *$ & $-2.8 \mathrm{E}-03$ & $-4.22 * * *$ \\
\hline Cohabiting b & 0.07 & 0.46 & 0.05 & 0.34 & 0.03 & 0.17 & 0.11 & 0.70 & 0.11 & 0.73 \\
\hline Number of children under 14 & -0.05 & -0.66 & -0.05 & -0.73 & -0.05 & -0.74 & -0.03 & -0.40 & -0.01 & -0.14 \\
\hline Relative(s) working as entrepreneurs b & -0.88 & $-6.60 * * *$ & -0.89 & $-6.66 * * *$ & -0.81 & $-6.11 * * *$ & -0.79 & $-5.96 * * *$ & -0.76 & $-5.75 * * *$ \\
\hline \multicolumn{11}{|l|}{ Macroeconomic variables } \\
\hline GDP per capita (in logs) & 0.28 & 1.12 & 0.36 & 1.43 & -0.59 & $-2.29 * *$ & 0.37 & 1.48 & 0.36 & 1.50 \\
\hline Unemployment rate (\%) & -0.08 & $-4.07 * * *$ & -0.10 & $-4.86 * * *$ & -0.09 & $-4.80 * * *$ & -0.05 & $-2.70 * * *$ & -0.05 & $-2.81 * * *$ \\
\hline Rule of law (from -2.5 to 2.5 ) & -1.90 & $-9.16 * * *$ & -2.47 & $-8.76 * * *$ & -2.72 & $-12.28 * * *$ & -1.55 & $-7.30 * * *$ & -1.38 & $-6.56 * * *$ \\
\hline Services sector share (\%) & $-2.6 \mathrm{E}-03$ & -0.53 & $-7.7 \mathrm{E}-03$ & -1.48 & $-1.4 \mathrm{E}-02$ & $-2.78 * * *$ & $-6.1 \mathrm{E}-03$ & -1.23 & $-1.6 \mathrm{E}-03$ & -0.33 \\
\hline Constant & 2.65 & 1.04 & 2.51 & 0.99 & 11.17 & $4.23 * * *$ & 1.23 & 0.48 & 0.49 & 0.20 \\
\hline Number of observations & \multicolumn{2}{|c|}{7,417} & \multicolumn{2}{|c|}{7,417} & \multicolumn{2}{|c|}{7,417} & \multicolumn{2}{|c|}{7,016} & \multicolumn{2}{|c|}{7,016} \\
\hline Number of left-censored observations & \multicolumn{2}{|c|}{1,152} & \multicolumn{2}{|c|}{1,152} & \multicolumn{2}{|c|}{1,152} & \multicolumn{2}{|c|}{1,041} & \multicolumn{2}{|c|}{1,041} \\
\hline Number of individuals & \multicolumn{2}{|c|}{3,129} & \multicolumn{2}{|c|}{3,129} & \multicolumn{2}{|c|}{3,129} & \multicolumn{2}{|c|}{2,940} & \multicolumn{2}{|c|}{2,940} \\
\hline Log likelihood & \multicolumn{2}{|c|}{$-18,252.20$} & \multicolumn{2}{|c|}{$-18,247.82$} & \multicolumn{2}{|c|}{$-18,203.97$} & \multicolumn{2}{|c|}{$-17,285.17$} & $-17,27$ & 0.97 \\
\hline
\end{tabular}

Notes: a $d y / d x$ captures marginal effects on the uncensored latent variable, not the observed outcome. Given that our dependent variable is expressed in natural logarithms, these effects can be interpreted as the percent change in earnings with respect to predicted earnings for sample means in case of continuous variables. In the context of dummy variables, it reflects the percent change in earnings for a discrete change of the dummy variable from 0 to 1.

b Dummy variable

* $0.1>p \geq 0.05$; ** $0.05>p \geq 0.01$; *** $p<0.01$. 
Table 3. Transitions from own-account worker to employer

\begin{tabular}{|c|c|c|c|c|c|c|c|c|c|c|}
\hline & \multicolumn{2}{|c|}{ Model I } & \multicolumn{2}{|c|}{ Model II } & \multicolumn{2}{|c|}{ Model III } & \multicolumn{2}{|c|}{ Model IV } & \multicolumn{2}{|c|}{ Model V } \\
\hline Predicted probability $(y)$ & \multicolumn{2}{|c|}{0.1284} & \multicolumn{2}{|c|}{0.1218} & \multicolumn{2}{|c|}{0.1244} & \multicolumn{2}{|c|}{0.1211} & \multicolumn{2}{|c|}{0.1221} \\
\hline Independent variables $(x)$ & $\frac{d y / d x}{y} \%$ & t-stat. & $\frac{d y / d x}{y} \%$ & t-stat. & $\frac{d y / d x}{y} \%$ & t-stat. & $\frac{d y / d x}{y} \%$ & t-stat. & $\frac{d y / d x}{y} \%$ & t-stat. \\
\hline
\end{tabular}

Educational attainment (macro level)

Tertiary (ISCED97 5-6) (\%; national data)

Secondary + Tertiary (ISCED 97 3-6) (\%; national data)

Tertiary (ISCED $975-6$ ) (\%; regional data)

$5.91 \quad 10.91 * * *$

Secondary + Tertiary (ISCED 97 3-6) (\%; regional data)

Educational attainment (micro level)

Basic education b (ref.)

Secondary education $b$

$28.36-4.69 *$

Tertiary education $\mathrm{b}$

$3.83^{* * *}$

$8.45 \quad 1.38$

$24.04 \quad 3.74 * * *$

$23.24 \quad 3.59$ ***

Demographics

Female ${ }^{b}$

Age (18-65)

Age (squared)

Cohabiting $b$

Number of children under 14

Relative(s) working as entrepreneurs ${ }^{b}$

$32.96 \quad 4.54$ *** $\quad 23.71 \quad 3.20 * * *$

$18.20 \quad 2.55$ **

$27.54 \quad 3.59$ ***

$29.46 \quad 3.82 * * *$

Macroeconomic variables

GDP per capita (in logs)

Unemployment rate $(\%)$

Rule of law (from -2.5 to 2.5 )

$\begin{array}{llll}-25.99 & -5.32 * * * & -28.68 & -5.63\end{array}$

$\begin{array}{llll}-0.36 & -0.16 & -0.41 & -0.18\end{array}$

$\begin{array}{llll}-9.5 \mathrm{E}-03 & -0.35 & -1.1 \mathrm{E}-02 & -0.37\end{array}$

$-28.95-5.86 * * *$

$-28.46-5.47 * * *$

$-27.93-5.41 * * *$

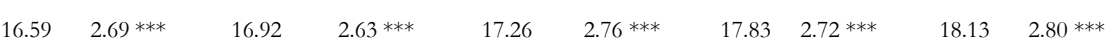

$\begin{array}{llllllllll}-1.00 & -0.35 & -1.36 & -0.46 & -0.49 & -0.17 & -2.13 & -0.70 & -2.28 & -0.75\end{array}$

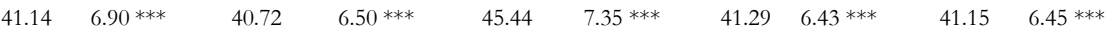

Services sector share $(\%)$

$-2.22-3.48 * * *$

$-59.15-7.27 * * *$

$-1.17-6.29 * * *$

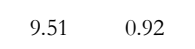

$-5.42-7.25 * * *$

$-151.98-12.60 * * *$

$-2.08-9.79 * * *$ $\begin{array}{llll}-37.98 & -3.80 * * * & 7.68 & 0.76\end{array}$

$\begin{array}{llll}-2.26 & -3.34 * * * & -4.11 & -5.72 * * *\end{array}$

$-96.88-10.57 * * * \quad-117.83-10.70 * * *$

$\begin{array}{llll}-1.98 & -9.47 * * * & -0.69 & -3.44 * * *\end{array}$
$-4.97 \quad-0.52$

$-3.20-4.51 * * *$

$-92.77-10.31 * * *$

$-0.67-3.28 * * *$

\begin{tabular}{lcccc}
\hline Number of observations & 14,900 & 14,900 & 14,900 & 13,709 \\
Number of transitions & 2,167 & 2,167 & 2,167 & 1,918 \\
Log likelihood & $-6,040.9$ & $-5,981.6$ & $-5,992.5$ & $-5,381.5$ \\
\hline
\end{tabular}

Notes: $\quad$ a For continuous variables, $[(d y / d x) / y] \%$ captures marginal effects, but expressed in relative terms with respect to predicted probabilities for sample means. In the context of dummy variables, it reflects the impact for a discrete change of the dummy variable from 0 to 1 .

b Dummy variable

* $0.1>p \geq 0.05 ; * * 0.05>p \geq 0.01 ; * * * p<0.01$. 
Table 4. Survival model: Departure from work as employer

-Single risk model: Exits to own-account work, paid-employment, unemployment and inactivity-

\begin{tabular}{|c|c|c|c|c|c|c|c|c|c|c|}
\hline & \multicolumn{2}{|c|}{ Model I } & \multicolumn{2}{|c|}{ Model II } & \multicolumn{2}{|c|}{ Model III } & \multicolumn{2}{|c|}{ Model IV } & \multicolumn{2}{|c|}{ Model V } \\
\hline Predicted probability $(y)$ & & & & & & & & & & \\
\hline Independent variables $(x)$ & $\frac{d y / d x}{y} \%$ & t-stat. & $\frac{d y / d x}{y} \%$ & t-stat. & $\frac{d y / d x}{y} \%^{a}$ & t-stat. & $\frac{d y / d x}{y} \%^{a}$ & t-stat. & $\frac{d y / d x}{y} \%^{a}$ & t-stat. \\
\hline
\end{tabular}

Educational attainment (macro level)

Tertiary (ISCED97 5-6) (\%; national data)

Secondary + Tertiary (ISCED97 3-6) (\%; national data)

Tertiary (ISCED97 5-6) (\%; regional data)

Secondary + Tertiary (ISCED 97 3-6) (\%; regional data)

$-2.33-2.84 * * *$

Educational attainment (micro level)

Basic education b (ref.)

Secondary education ${ }^{b}$

$\begin{array}{rrrrrrrrrr}-24.50 & -3.29 * * * & -23.4 & -3.13 * * * & -13.81 & -1.72 * & -25.67 & -3.24 * * * & -22.93 & -2.81 * * * \\ -22.46 & -2.79 * * * & -20.24 & -2.47 * * & -16.04 & -1.89 * & -20.10 & -2.30 * * & -17.61 & -1.97 * * \\ & & & & & & & & & \\ 20.47 & 2.46 * * & 20.71 & 2.49 * * & 21.61 & 2.57 * * & 22.93 & 2.51 * * & 23.16 & 2.53 * * \\ -8.06 & -2.55 * * & -7.82 & -2.47 * * & -6.97 & -2.20 * * & -7.29 & -2.15 * * & -7.11 & -2.10 * * \\ 9.7 \mathrm{E}-02 & 2.55 * * & 9.4 \mathrm{E}-02 & 2.51 * * & 8.5 \mathrm{E}-02 & 2.26 * * & 8.7 \mathrm{E}-02 & 2.17 * * & 8.5 \mathrm{E}-02 & 2.12 * * \\ -18.05 & -1.67 * & -18.69 & -1.72 * & -18.91 & -1.73 * & -9.82 & -0.87 & -9.49 & -0.84 \\ 3.44 & 0.85 & 3.98 & 0.98 & 3.11 & 0.76 & 5.99 & 1.38 & 5.55 & 1.27 \\ -22.19 & -3.25 * * * & -21.52 & -3.14 * * * & -25.67 & -3.74 * * * & -19.16 & -2.58 * * * & -20.27 & -2.73 * * *\end{array}$

Demographics

Female b

Age (18-65)

Age (squared)

Cohabiting $\mathrm{b}$

Number of children under 14

Relative(s) working as entrepreneurs b

$-22.19-3.25 * * *$

$-21.52-3.14 * * *$

$-1.30-4.60 * * *$

$0.01 \quad 0.02$

$-0.39-1.68 *$

Duration dependence

Job tenure as employer (in $\operatorname{logs}$ )

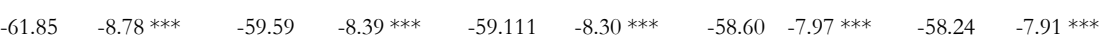

Macroeconomic variables

GDP per capita (in logs)

Unemployment rate (\%)

Rule of law (from -2.5 to 2.5 )

Services sector share $(\%)$

Number of observations

Number of spells

Number of censored spells

Number of completed spells

Log likelihood

\begin{tabular}{rrr} 
& & \\
-171.52 & $-10.30^{* * *}$ & -179.5 \\
7.42 & $6.54 * * *$ & 10.1 \\
148.63 & $10.25 * * *$ & 188.5 \\
0.32 & 1.25 & \\
& & \\
\hline
\end{tabular}

$\begin{array}{ccccc}4,023 & 4,023 & 4,023 & 3,637 & 3,637 \\ 2,179 & 2,179 & 2,179 & 1,929 & 1,929 \\ 1,303 & 1,303 & 1,303 & 1,163 & 1,163 \\ 876 & 876 & 876 & 766 & 766 \\ -1,919.3 & -1,915.2 & -1,908.7 & -1,713.6 & -1,712.17\end{array}$

Notes: a For continuous variables, $[(d y / d x) / y] \%$ captures marginal effects, but expressed in relative terms with respect to predicted probabilities for sample means. In the context of dummy variables, it reflects the impact for a discrete change of the dummy variable from 0 to 1.

b Dummy variable

* $0.1>p \geq 0.05 ; * * 0.05>p \geq 0.01 ; * * * p<0.01$. 


\section{Appendix: Variable definitions and descriptive statistics}

Table A: Variable definitions

Variable

Survival as entrepreneur

Earnings as self-employed

Transition from own-account work to employer

Survival as employer

\section{Educational attainment (macro level)}

Tertiary (ISCED 97 5-6) (\%; national data)

Secondary + Tertiary (ISCED 97 3-6) (\%; national data)

Tertiary (ISCED 97 5-6) (\%; regional data)

Secondary + Tertiary (ISCED 97 3-6) (\%; regional data)

Educational attainment (micro level)

Basic education

Secondary education

Tertiary education

Demographic characteristics

Female

Age

Cohabiting

Number of children under 14

Relative(s) working as entrepreneurs

\section{Duration dependence}

Job tenure as entrepreneur

Job tenure as employer

Other macroeconomic variables

National GDP per capita (levels)

National unemployment rate

Rule of law

Services sector share

Robustness checks

National GDP per capita (growth rates)

Active in innovative sector

\section{Description}

\section{Dependent variables}

Dependent variable equals 1 for individuals who are entrepreneur in period $t-1$ and enter paid-employment in period $t$. The variable equals 2 for individuals who are entrepreneur in period $t-1$ and enter unemployment or inactivity in period $t$. Finally, the variable equals 0 for individuals who are entrepreneur in periods $t-1$ and $t$, or the information about the labor market status in $t$ is censored.

Self-employment incomes earned during the year prior to the interview, converted to average $€$ of 1996, being corrected by Purchasing Power Parity (across countries) and Harmonised Consumer Price Index (over time). This variable is expressed in natural logarithms. When running earnings equations, all explanatory variables are 1-year lagged in order to avoid timing mismatch with earnings.

Dependent variable equals 1 for individuals who are own-account worker in period $t-1$ and become employer in period $t$. The variable equals 0 for individuals who are own-account worker in periods $t-1$ and $t$.

Dependent variable equals 1 for individuals who are employer in period $t-1$ and exit employership in period $t$. The variable equals 0 for individuals who are employer in periods $t-1$ and $t$, or the information about the labor market status in $t$ is censored.

\section{Independent variables}

Percentage of the active population from 25 to 64 years with at least first stage of tertiary education: ISCED 1997 categories 5 and 6 (source: Eurostat). This variable is generated at the country level (source: Eurostat).

Percentage of the active population from 25 to 64 years with at least upper secondary education: ISCED-1997 categories 3 to 6 (source: Eurostat). This variable is generated at the country level (source: Eurostat).

Percentage of the active population from 25 to 64 years with first and second stage of tertiary education: ISCED-1997 categories 5 and 6 (source: Eurostat). This variable is generated at the regional level -NUTS 1(source: Eurostat).

Percentage of the active population from 25 to 64 years with at least upper secondary education: ISCED-1997 categories 3 to 6 (source: Eurostat). This variable is generated at the regional level -NUTS 1- (source: Eurostat).

Dummy equals 1 for individuals with less than second stage of secondary level education (ISCED-1997, 0-2).

Dummy equals 1 for individuals with second stage of secondary level education (ISCED-1997, 3).

Dummy equals 1 for individuals with recognized third level education (ISCED-1997, 5 or 6).

Dummy equals 1 for females.

Age reported by the individual.

Dummy equals 1 for cohabiting individuals.

Number of children younger than 14 living within the household.

Dummy equals 1 if there are any in the household.

Number of years as entrepreneur. Variable expressed in natural logarithms.

Number of years as employer. Variable expressed in natural logarithms.

Real GDP per capita expressed in PPP US\$ of 1990 (source: OECD). Variable expressed in natural logarithms. Harmonized annual unemployment rate (source: OECD).

Time-dependent index for the degree of regulation enforcement. This variable ranges from -2.5 to 2.5 (source: World Bank).

Share of services sector in total employment (source: OECD).

Real GDP per capita expressed in PPP US\$ of 1990 (source: OECD). Variable expressed in growth rates.

Dummy equals 1 for entrepreneurs being active in an innovative sector, defined as a sector with above-average R\&D-intensity: R\&D-expenditures over R\&D-employment (source: own calculations based on OECD statistics). The benchmark (average) R\&D-intensity relates to the average R\&D-intensity in 2001 over 12 countries and 14 sectors (i.e., 168 country-sector combinations). By means of the Nomenclature of Economic Activities (NACE-93), the following 14 sectors have been used:

$\mathrm{C}+\mathrm{E}$ Mining and quarrying + Electricity, gas and water supply.

DA Manufacture of food products, beverages and tobacco.

$\mathrm{DB}+\mathrm{DC}$ Manufacture of textiles, clothing and leather products.

DD+DE Manufacture off wood and paper products; publishing and printing.

DF-DI Manufacture of coke, refined petroleum/chemicals/rubber/plastic and other non-metallic mineral products.

DJ+DK Manufacture of metal products, machinery and equipment.

DL-DN Other manufacturing.

F Construction 
I Transport, storage and communication.

J Financial intermediation.

$\mathrm{K}$ Real estate, renting and business activities.

L-Q Public administration and defence; compulsory social security; education; health and social work; other community, social and personal service activities; private households with employed persons; extra-territorial organizations and bodies.

Table B. Descriptive statistics for each of the four analyses

\begin{tabular}{|c|c|c|c|c|c|c|c|c|}
\hline & \multicolumn{3}{|c|}{ Entrepreneurship survival } & \multicolumn{2}{|c|}{$\begin{array}{l}\text { Transitions from own- } \\
\text { account worker to } \\
\text { employer }\end{array}$} & \multicolumn{2}{|c|}{ Employership survival } & \multirow[t]{2}{*}{$\begin{array}{l}\text { Entrepre- } \\
\text { neurship } \\
\text { earnings }\end{array}$} \\
\hline Final destination & Censored & $\begin{array}{l}\text { Paid } \\
\text { employment }\end{array}$ & $\begin{array}{c}\text { Non- } \\
\text { employment }\end{array}$ & $\begin{array}{c}\text { Not } \\
\text { switching }\end{array}$ & Switching & Censored & $\begin{array}{c}\text { Own- } \\
\text { account } \\
\text { work/paid } \\
\text { or non } \\
\text { employ- } \\
\text { ments } \\
\end{array}$ & \\
\hline Number of spells & 3,962 & 1,501 & 884 & --- & --- & 1,303 & 876 & --- \\
\hline Number of observations & --- & $-\overline{--}$ & --- & 12,733 & 2,167 & --- & --- & 7,417 \\
\hline \multicolumn{9}{|l|}{ Educational attainment (macro level) } \\
\hline Tertiary (ISCED 97 5-6) (\%; national data) & $\begin{array}{c}21.86 \% \\
(7.55)\end{array}$ & $\begin{array}{l}21.18 \% \\
(7.05)\end{array}$ & $\begin{array}{l}20.33 \% \\
(6.70)\end{array}$ & $\begin{array}{l}20.98 \% \\
(6.73)\end{array}$ & $\begin{array}{l}20.91 \% \\
(6.84)\end{array}$ & $\begin{array}{l}21.76 \% \\
(7.87)\end{array}$ & $\begin{array}{l}22.36 \% \\
(6.67)\end{array}$ & $\begin{array}{l}21.34 \% \\
(7.23)\end{array}$ \\
\hline $\begin{array}{l}\text { Secondary + Tertiary (ISCED } 97 \text { 3-6) } \\
(\% ; \text { national data) }\end{array}$ & $\begin{array}{l}56.79 \% \\
(16.91)\end{array}$ & $\begin{array}{l}53.87 \% \\
(17.12)\end{array}$ & $\begin{array}{l}52.62 \% \\
(15.23)\end{array}$ & $\begin{array}{l}52.37 \% \\
(15.78)\end{array}$ & $\begin{array}{l}52.76 \% \\
(15.79)\end{array}$ & $\begin{array}{l}55.67 \% \\
(16.41)\end{array}$ & $\begin{array}{l}53.24 \% \\
(16.14)\end{array}$ & $\begin{array}{l}56.23 \% \\
(16.81)\end{array}$ \\
\hline \multicolumn{9}{|l|}{ Educational attainment (micro level) } \\
\hline $\begin{array}{l}\text { Basic education } \\
\text { Secondary education } \\
\text { Tertiary education }\end{array}$ & $\begin{array}{l}41.39 \% \\
32.86 \% \\
25.74 \%\end{array}$ & $\begin{array}{l}41.77 \% \\
30.71 \% \\
27.51 \%\end{array}$ & $\begin{array}{l}52.49 \% \\
29.41 \% \\
18.10 \%\end{array}$ & $\begin{array}{l}49.67 \% \\
28.66 \% \\
21.67 \%\end{array}$ & $\begin{array}{l}45.59 \% \\
31.98 \% \\
22.43 \%\end{array}$ & $\begin{array}{l}42.67 \% \\
34.38 \% \\
22.95 \%\end{array}$ & $\begin{array}{l}47.49 \% \\
29.68 \% \\
22.83 \%\end{array}$ & $\begin{array}{l}41.09 \% \\
33.29 \% \\
25.62 \%\end{array}$ \\
\hline \multicolumn{9}{|l|}{ Demographic characteristics } \\
\hline Females & $35.46 \%$ & $33.84 \%$ & $63.12 \%$ & $29.79 \%$ & $26.17 \%$ & $25.33 \%$ & $27.28 \%$ & $32.71 \%$ \\
\hline Average age (years) & $\begin{array}{c}39.5 \\
(9.95)\end{array}$ & $\begin{array}{l}38.0 \\
(9.79)\end{array}$ & $\begin{array}{c}41.6 \\
(11.62)\end{array}$ & $\begin{array}{c}41.9 \\
(9.33)\end{array}$ & $\begin{array}{c}40.6 \\
(9.35)\end{array}$ & $\begin{array}{l}42.9 \\
(9.29)\end{array}$ & $\begin{array}{l}41.9 \\
(9.55)\end{array}$ & $\begin{array}{c}39.9 \\
(9.57)\end{array}$ \\
\hline Cohabiting & $74.26 \%$ & $70.55 \%$ & $73.53 \%$ & $81.02 \%$ & $81.91 \%$ & $84.04 \%$ & $81.62 \%$ & $77.16 \%$ \\
\hline Number of children under 14 & $\begin{array}{c}0.66 \\
(0.94)\end{array}$ & $\begin{array}{c}0.69 \\
(0.94)\end{array}$ & $\begin{array}{c}0.65 \\
(0.98)\end{array}$ & $\begin{array}{c}0.69 \\
(0.94)\end{array}$ & $\begin{array}{c}0.72 \\
(0.93)\end{array}$ & $\begin{array}{c}0.66 \\
(0.92)\end{array}$ & $\begin{array}{c}0.70 \\
(0.91)\end{array}$ & $\begin{array}{c}0.72 \\
(0.96)\end{array}$ \\
\hline Relative(s) working as entrepreneurs & $34.40 \%$ & $26.78 \%$ & $33.71 \%$ & $25.84 \%$ & $33.87 \%$ & $39.22 \%$ & $32.53 \%$ & $31.79 \%$ \\
\hline \multicolumn{9}{|l|}{ Duration dependence } \\
\hline Average job tenure as entrepreneur (years) & $\begin{array}{c}2.56 \\
(1.76)\end{array}$ & $\begin{array}{c}1.60 \\
(1.00)\end{array}$ & $\begin{array}{c}1.48 \\
(0.92)\end{array}$ & --- & --- & --- & --- & --- \\
\hline Average job tenure as employer (years) & --- & --- & --- & --- & --- & $\begin{array}{c}2.13 \\
(1.43)\end{array}$ & $\begin{array}{c}1.45 \\
(0.83)\end{array}$ & --- \\
\hline \multicolumn{9}{|l|}{ Macroeconomic variables } \\
\hline National GDP per capita (PPP US\$ of 1990) & $\begin{array}{l}16,586.5 \\
(4,642.5)\end{array}$ & $\begin{array}{l}15,445.6 \\
(4,028,8)\end{array}$ & $\begin{array}{l}15,024.8 \\
(4,182.3)\end{array}$ & $\begin{array}{l}14,231.6 \\
(4,099.0)\end{array}$ & $\begin{array}{c}13627.1 \\
(4,255.4)\end{array}$ & $\begin{array}{l}15,117.6 \\
(4,587.6)\end{array}$ & $\begin{array}{l}13,415.1 \\
(4,303.4)\end{array}$ & $\begin{array}{l}16,117.5 \\
(4,462.1)\end{array}$ \\
\hline National unemployment rate (\%) & $\begin{array}{l}8.15 \% \\
(3.38)\end{array}$ & $\begin{array}{l}9.30 \% \\
(3.84)\end{array}$ & $\begin{array}{l}9.87 \% \\
(3.82)\end{array}$ & $\begin{array}{c}10.08 \% \\
(3.95)\end{array}$ & $\begin{array}{c}10.06 \% \\
(3.20)\end{array}$ & $\begin{array}{l}8.56 \% \\
(2.76)\end{array}$ & $\begin{array}{l}9.82 \% \\
(3.16)\end{array}$ & $\begin{array}{l}8.59 \% \\
(3.35)\end{array}$ \\
\hline Rule of law (from -2.5 to 2.5 ) & $\begin{array}{c}1.322 \\
(0.393)\end{array}$ & $\begin{array}{c}1.366 \\
(0.378)\end{array}$ & $\begin{array}{c}1.301 \\
(0.378)\end{array}$ & $\begin{array}{c}1.336 \\
(0.389)\end{array}$ & $\begin{array}{c}1.258 \\
(0.399)\end{array}$ & $\begin{array}{c}1.208 \\
(0.411)\end{array}$ & $\begin{array}{c}1.249 \\
(0.412)\end{array}$ & $\begin{array}{c}1.312 \\
(0.392)\end{array}$ \\
\hline Services sector share (\%) & $\begin{array}{l}51.79 \% \\
(13.68)\end{array}$ & $\begin{array}{l}51.44 \% \\
(13.59)\end{array}$ & $\begin{array}{l}53.29 \% \\
(13.23)\end{array}$ & $\begin{array}{l}53.44 \% \\
(13.81)\end{array}$ & $\begin{array}{l}52.61 \% \\
(14.45)\end{array}$ & $\begin{array}{l}52.40 \% \\
(14.28)\end{array}$ & $\begin{array}{l}52.92 \% \\
(15.19)\end{array}$ & $\begin{array}{l}51.92 \% \\
(13.75)\end{array}$ \\
\hline \multicolumn{9}{|l|}{ Robustness check } \\
\hline Active in innovative sector ${ }^{a}$ & $35.41 \%$ & $30.21 \%$ & $30.50 \%$ & $35.16 \%$ & $36.96 \%$ & $32.83 \%$ & $33.50 \%$ & $32.32 \%$ \\
\hline
\end{tabular}

Notes: Standard deviations for continuous explanatory variables in parentheses.

${ }^{a}$ Excluding Denmark and Luxembourg. 
Table C. Regional information for the educational attainment level at the macro level

Country Regional disaggregation -NUTS 1-

\begin{tabular}{|c|c|}
\hline Austria & (i) Ostösterreich; (ii) Südösterreich; (iii) Westösterreich \\
\hline Belgium & (i) Région Bruxelles-capitale/Brussels hoofdstad gewest; (ii) Vlaams Gewest; (iii) Région Wallonne \\
\hline Denmark & (i) Denmark \\
\hline Finland & (i) Etelä-Suomi (incl. Åland); (ii) Itä-Suomi; (iii) Pohjois-Suomi \\
\hline France & (i) Île de France; (ii) Bassin Parisien; (iii) Nord - Pas-de-Calais; (iv) Est; (v) Ouest; (vi) Sud-Ouest; (vii) Centre-Est; (viii) Méditerranée \\
\hline Germany & $\begin{array}{l}\text { (i) Baden-Württemberg; (ii) Bayern; (iii) Berlin; (iv) Brandenburg; (v) Bremen; (vi) Hamburg; (vii) Hessen; (viii) Mecklenburg-Vorpommern; (ix) } \\
\text { Niedersachsen; (x) Nordrhein-Westfalen; (xi) Sachsen; (xii) Sachsen-Anhalt; (xiii) Schleswig-Holstein; (xiv) Thüringen; (xv) Rheinland-Pfalz + } \\
\text { Saarland }\end{array}$ \\
\hline Greece & (i) Voreia Ellada; (ii) Kentriki Ellada; (iii) Attiki; (iv) Nisia Aigaiou, Kriti \\
\hline Ireland & (i) Ireland \\
\hline Italy & $\begin{array}{l}\text { (i) Nord Ovest; (ii) Lombardia; (iii) Nord Est; (iv) Emilia-Romagna; (v) Centro; (vi) Lazio; (vii) Abruzzo-Molise; (viii) Campania; (ix) Sud; (x) Sicilia; } \\
\text { (xi) Sardegna }\end{array}$ \\
\hline Luxembourg & (i) Luxembourg \\
\hline Netherlands & (i) Netherlands \\
\hline Portugal & (i) Norte; (ii) Algarve; (iii) Centro; (iv) Lisboa; (v) Alentejo; (vi) Região Autónoma dos Açores; (vii) Região Autónoma da Madeira \\
\hline Spain & (i) Noroeste; (ii) Noreste; (iii) Comunidad de Madrid; (iv) Centro; (v) Este; (vi) Sur; (vii) Canarias \\
\hline UK & $\begin{array}{l}\text { (i) Northwest; (ii) Yorkshire and The Humber; (iii) East Midlands; (iv) West Midlands: (v) East of England; (vi) South East; (vii) South West; (viii) } \\
\text { Wales; (ix) Scotland; (x) Northern Ireland }\end{array}$ \\
\hline
\end{tabular}

Notes: Regional information is available for the period 1999-2001. For 1994-1998 we used the observation corresponding to 1999.

Denmark, Ireland and Luxembourg are NUTS 1 themselves.

Regional data for the Netherlands is not available at the ECHP (we use the country level values in the regional analysis). 
